Zabytkoznawstwo i Konserwatorstwo XLII, Torun 2011

\title{
Niderlandzki modlitewnik 83 \\ ze zbiorów toruńskich - przyczynek do badań nad warsztatem iluminatorskim w późnym średniowieczu*
}

\section{Wprowadzenie}

WTgrupie prywatnych ksiązek dewocyjnych z okresu średniowiecza, przechowywanych w Zbiorach Specjalnych Biblioteki Uniwersyteckiej w Toruniu, znajduje się zachowany w dobrym stanie kodeks Godzinek Geerta Groote (cod. 83/I), nabyty w 1687 roku do Biblioteki Wallenrodów ${ }^{1}$ i aż do 1945 roku należący wraz z nią do za-

Za wnikliwą lekturę tekstu i cenne uwagi merytoryczne pragnę podziękować pani dr Marcie Czyżak z Sekcji Rękopisów przy Zbiorach Specjalnych Biblioteki Głównej UMK w Toruniu. Pani Barbarze Wojdyło, kierownikowi Oddziału Konserwacji i Zabezpieczenia Zbiorów BG, składam podziękowania za konsultację konserwatorska. Za życzliwe podejście do prowadzonych przeze mnie badań i zgodę na publikację kodeksu dziękuję Dyrekcji Biblioteki UMK.

1 Księga stanowi jeden $\mathrm{z}$ trzynastu manuskryptów, zachowanych $\mathrm{z}$ dawnych zbiorów Biblioteki Wallenrodów. Na wyklejce znajduje się ekslibris: WALLENRODIADUM MAGNIS MAIORIBUS ORTA HUNC RELIQUIS IUNXIT BIBLIO- 
sobu Staats- und Universitätsbibliothek w Królewcu². To niewielkie $(18,5 \times 13,5 \mathrm{~cm})$ dzieło zostało spisane bastarda na delikatnym, obustronnie szlifowanym pergaminie i bogato ozdobione inicjałami, wypustkami kaligraficznymi oraz marginalnymi bordiurami roślinnymi, które jednak nie wszędzie zostały wykończone. Całość liczy obecnie 127 kart, połączonych w 17 składek $^{3}$ i oprawnych w tłoczoną skórę. W 1995 roku rękopis został poddany pełnej konserwacji - przywróciła ona blokowi księgi zwartość i uwydatniła jakość iluminacji ${ }^{4}$. Jedyną jak dotąd próbę omówienia i oceny stylu zdobień modlitewnika zawdzięczamy publikacjom Ali-

THECA LIBRIS UTERE CONCESSO LECTOR TIBI MUNERE RITE CUNCTAQUE PATRONIS FAUSTA PRECARE MEIS. W okienku wyklejki widnieje słabo czytelna inskrypcja, naniesiona na żółtawym gruncie na deskę oprawy: Hic Liber publice / WALLENRODIANAE Biblio / thecale ad]latus est / MDCLXXXVII Mense Majo. Kodeks został odnotowany jako Belgisches Breviarium przez R. J. Bocka, Nachrichten über Handschriften und alten Druckwerken der Gräflich von Wallenrodtischen Bibliothek zu Königsberg in Preußen, „Neue Preußische Provinzialblätter”, 1829, Bd. 2, Nr. 36, s. 516. Ujęto go także jako Ritauale Belgicum w spisie inwentarzowym z 1849 r., opublikowanym przez Päslera - zob. R. G. Päsler, Die Handschriften der Wallenrodtschen Bibliothek. Zweiter Beitrag zur Rekonstruktion der Handschriftensammlung der ehem. Staats- und Universitätsbibliothek Königsberg, „Berichte und Forschungen. Jahrbuch des Bundesinstituts für Kultur und Geschichte der Deutschen im östlichen Europa", 2004, Bd. 12, s. 39, 47.

2 R. G. Päsler, Katalog der mittelalterlichen deutschsprachigen Handschriften der ehemaligen Staats- und Universitätsbibliothek. Königsberg. Nebst Beschreibungen der mittelalterlichen deutschsprachigen Fragmente des ehemaligen Staatsarchiv Königsberg, hrsg. von U. Meves, München 2000 („Schriften des Bundesinstituts für ostdeutsche Kultur und Geschichte”, Bd. 15, hrsg. von E. Grunewald), s. 193-194. Tam też zestawienie dotychczasowej literatury.

3 Ternion oraz kwaterniony z pewnymi nieregularnościami, spowodowanymi wycięciem kilku kart. Należy skorygować układ, podany przez Päslera (Katalog der mittelalterlichen). Układ składek kodeksu, po weryfikacji Marty Czyżak, jest następujący: I. 3-1+3 (f. 1-5), II. 4+4-2 (f. 6-11), III. 4+4-1 (f. 12-18; wycięta karta między kartami 16 i 17), IV-IX. 4+4 (f. 19-66), X. 5-1+5 (f. 67-75), XI-XVI. 4+4 (f. 76-123), XVII. 4-2 + 4-2 (f. 124-127, wycięte cztery karty).

4 Konserwację przeprowadzono w Pracowni Konserwacji Zbiorów Biblioteki Głównej UMK, zob. B. Wojdyło, Dokumentacja konserwatorska kodeksu staroniemieckiego na pergaminie o nr. inw. 83, Toruń 1995 [mps]. 
cji Karłowskiej-Kamzowej ${ }^{5}$. Wskazała ona na jego świeckie bogactwo, próbując określić pracujące przy wykonywaniu zdobień indywidualności twórcze i scharakteryzować ich odrębne maniery.

Trudno dziś ustalić dokładnie pierwotny kontekst funkcjonalny kodeksu - nie wiadomo, komu pierwotnie służył i w jakich okolicznościach trafil do zbiorów Wallenrodów. Godzinki, przetłumaczone przez Geerta Grootego w ostatnich latach jego życia (1383-1384) z łaciny na język niderlandzki, były najpopularniejszą książką dewocyjną w północnych Niderlandach, poczytną także w północnych Niemczech ${ }^{6}$. Toruński egzemplarz - jeden z kilkuset znanych średniowiecznych odpisów tego przekładu - nie zawiera pełnego tekstu Grootego. W obręb kodeksu wchodzą Godzinki o Najswietszej Maryi Pannie (Getijden der Heilige Maagd) bez prologu - 12-68vad , Godinki o Madrości Przedwiecznej (Getijden der Eenwige Wijsheid) $-69^{\mathrm{r}}-102^{\mathrm{r}}$ oraz Godzinki o Duchu św. (Getijden van de Heilige Geest) $-103^{\mathrm{r}}-127^{\mathrm{r}}$. Całość jest poprzedzona kalendarzem diecezji utrechckiej, w którym brakuje karty z czerwcem ${ }^{8}$. Księga nie zawiera krótkich ani dłu-

5 A. Karłowska-Kamzowa, Dekoracje malarskie gotyckich rekopisów iluminowanych ze zbiorów Biblioteki Uniwersyteckiej w Toruniu, [w:] Studia o dziatalności i zbiorach Biblioteki Uniwersytetu Mikolaja Kopernika, cz. 4, pod red. B. Ryszewskiego, Toruń 1998, s. 140-141; eadem, Środowiska miejscowe, [w:] J. Domasłowski, A. Karłowska-Kamzowa, A. Labuda, Malarstwo gotyckie na Pomorzu Wschodnim (Prace Komisji Historii Sztuki, t. 17), Warszawa-Poznań 1990, s. 216.

${ }_{6}$ N. van Wijk, Inleiding, [w:] G. Grote, Getijdenboek, Naar het Haagse Handschrift 133 E 21, ed. by N. van Wijk, Leiden 1940, s. 2.

7 Zbliżony układ tekstów, niekiedy wzbogacony o dodatkowe officia, znajdujemy w kilku rękopisach, skatalogowanych przez N. van Wijka, np. z Koninklijke Bibliotheek w Brukseli, kodeks 3040; z Landesbibliothek w Fuldzie (AA 132); z Paulinische Bibliothek w Münster (419 [783] oraz 421 [779]). Zob. N. van Wijk, op. cit., s. $10-19$.

8 Rubrą są wyszczególnione wspomnienia następujących świętych: Ponciaen (14 I), Agniet (21 I), Pouwels begeert (25 I), Mathijs apostel (24 II), Gheertrunt ioncf. (17 III), Philips en. iacob (1 V), Pancraes martelaer (12 V), Seruaes bisscop (13 V), Maria Magdalena (22 VII), Iacob apostel (25 VII), Lourens martelaer (10 VIII), Bertelmeus apostel (24 VIII), Lambert bisscop (17 IX), Matheus apl' en evan (21 IX), Mauritius mit s.g. (22 IX), Michel arche engel (29 IX), Victoer mit. s. ghe (10 X), Symon en Iude apl (28 X), Wilbrordt bisscop (7 XI), Mertijn bisscop (11 XI), Lebunijn confessoer (12 XI), Katharine ioncf (25 XI), Andreas apostel (30 XI), Nicholas bisscop (6 XII), Thomas Apostel (27 XII), Steven eerte mr (26 XII), Ian apostel en evn. (27 XII). Wyeksponowano następujące święta: Derchien dach (6 II), Onser vrou lichtmis (4 II), Peter 
gich Godzinek o sww. Krayzįu (Korte / Lange Getijden van bet H. Kruis), ani Psalmów pokutnych i Litanii.

Mimo nieznanej proweniencji wydaje się prawdopodobne, że kodeks stanowi dobry przykład postaw dewocyjnych, szerzących się wśród europejskiego laikatu w XV wieku dzięki niderlandzkiej devotio moderna. Wyeksponowanie pierwszej części modlitw przez bogatszą formułę dekoracji oraz zaakcentowanie świąt maryjnych $\mathrm{w}$ kalendarzu wpisuje się w powszechny wzrost czci maryjnej w późnym średniowieczu. Świecki usus modlitewnika może znajdować potwierdzenie w szlachetnej oprawie z tłoczonej skóry oraz w dekoracji malarskiej (przypuszczalnie bogatszej niegdyś o niezachowana, przynajmniej jedną miniaturę) ${ }^{9}$. Kodeks zachwyca obfitością rubrykowań i złoceń - połyskliwych i matowych (te ostatnie są już niestety silnie wytarte), różnorodnością zdobień inicjałów, grupujących się w trzy odrębne typy, oraz bogactwem konsekwentnej dekoracji ornamentalnej (il. 1-4). Fakt, że nigdy nie został ostatecznie wykończony, nie umniejsza jego luksusowego charakteru. Znane sa przykłady manuskryptów, zachowanych w podobnym stanie i użytkowanych przez swoich fundatorów. Słynne Bardzo Bogate Godz̨inki księcia de Berry wskazują, że zawsze była możliwość naniesienia wykończeń w późniejszym czasie, choć było to raczej rzadko praktykowane ${ }^{10}$.

ad cathedram (22 II), Onse vrou boetscap (25 III), Theilich cruns genod (3 V), Onse vrouwe vadig (2 VII), Mertijns uheven (4 VII), Peter ghevangen (1 IX), Onse vrouwe hemelut (15 VIII), Sian onthoes (29 VIII), Ons V rouwe Geboert (8 IX), Theilige cruus uheve (14 IX), Remeyn ende baue (1 X), Alle beilighen (1 XI), Alle zielen (2 XI), Onse vrou ontfage (8 XII), Korsdach (25 XII), Alre kinder dach (29 XII).

9 R. G. Päsler, Katalog der mittelalterlichen, s. 193, przypuszcza, że było ich więcej, niemniej dokładna analiza modlitewnika wskazuje, że można założyć istnienie jednej miniatury - poprzedzającej Godzinki o NMP. Karta poprzedzająca folio $12^{\mathrm{r}}$ - incipit godzinek, została wycięta, a przez porównanie z innymi podobnymi kodeksami można założyć, że znajdowała się tam miniatura, ukazująca Zwiastowanie. Przy pozostałych kartach początkowych nie można stwierdzić wycięcia kart z ewentualnymi miniaturami. 1992, s. 47.

10 J. J. G. Alexander, Medieval illuminators and their methods of work, New Haven 


\section{Inicjały}

Tekst modlitewnika jest pisany w 17 -wersowych blokach (obustronnie liniowanych), ma liczne rubrykowania ${ }^{11} \mathrm{i}$ jest usiany wysokimi na jeden werset inicjałami kaligraficznymi, w całości złotymi lub błękitnymi. W partii Godzinek o NMP inicjały błękitne sa dodatkowo obramione drobnym cynobrowym filigranem pączkowym, który na ogół przechodzi w wypustki o formie zamaszyście kreślonych, falistych wąsów z drobnymi ziarenkami, rozchodzących się po całym marginesie ${ }^{12}$ (il. 5). Obok tych skromnych zdobień kaligraficznych występuje też wiele inicjałów średnich w ramkach (w partii kalendarza wysokich na pięć, w tekście na około dwa-trzy wersy), rozpoczynających poszczególne części godzin - psalmy, hymny, kolekty itd. (il. 6). Wcięcie inicjałów w tekst dowodzi współpracy pomiędzy kopista tekstu a dekoratorami. Litery inicjałów w ramkach są wypełnione złotem płatkowym, okonturowane czernią i umieszczone na dwustrefowym, purpurowo-błękitnym tle ${ }^{13}$. Ich dekoracyjne oddziaływanie zostało wzmocnione dzięki nieregularnym kształtom pól, które podążają za szeryfami liter i są „wykrajane” za pomoca głębokich, półkolistych wcięć. Poza tym tło jest nakrapiane drobnymi białymi punkcikami, a światła liter częstokroć zdobią malowane biela, linearne gwiazdki, lilijki, gałązi czy kratkowania. Pojawiają się także kaligraficzne wypustki ${ }^{14}$ - będzie jeszcze o nich mowa.

Osobna grupę dekoracji literowej stanowią hierarchicznie ważniejsze inicjały na złotych polach, o wysokości od trzech do pięciu wersów (zob. il. 2-3), znajdujące się głównie na początkach godzin ${ }^{15}$, rzadziej

11 Rubra pisano introity do części godzinek, przejścia do kolejnych godzin kanonicznych, nazwy modlitw (antiffen, completa, Ymnus, ps. itd.) i ich zakończenia (amen). Częstokroć pojedyncze czerwone kreski podkreślaja początki poszczególnych zdań (co jest reguła dla Godzinek o Madrości i Godzinek o Duchu św.).

12 Na przykład: $25^{\mathrm{r}}, 27^{\mathrm{r}}, 27^{\mathrm{v}}, 28^{\mathrm{v}}$.

13 Na przykład: $4^{\mathrm{r}}, 5^{\mathrm{r}}, 7^{\mathrm{r}}$ (kalendarz) i $33^{\mathrm{r}}, 40^{\mathrm{v}}, 101^{\mathrm{v}}, 104^{\mathrm{v}}$. Pojedynczy przypadek tła całkowicie cynobrowego $-34^{\mathrm{r}}$.

14 Na przykład: 40 $91^{\mathrm{r}}, 96^{\mathrm{r}}, 99^{\mathrm{v}}, 100^{\mathrm{r}}$.

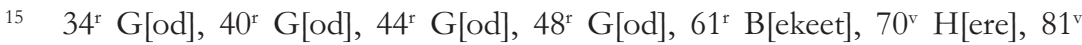

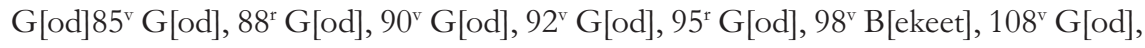
$112^{\mathrm{v}} \mathrm{G}[\mathrm{od}], 116^{\mathrm{r}} \mathrm{G}[\mathrm{od}], 119^{\mathrm{v}} \mathrm{G}[\mathrm{od}], 123^{\mathrm{r}} \mathrm{G}[\mathrm{od}], 126^{\mathrm{r}} \mathrm{B}$ [ekeet]. 
- w sekwencjach modlitw ${ }^{16}$. Malowane przypuszczalnie azurytem litery sa umieszczone na jednolicie pozłoconym tle o nieregularnym konturze z wcięciami. Błękitne korpusy liter ożywia delikatny, kreślony biela ornament piórkowy, który tworzy niekiedy w lasce pionowej segmenty drobnych rozet, a czasem "cieniuje” ja walorowo $\left(45^{\mathrm{r}}, 48^{\mathrm{v}}\right)$. W tej grupie wyróżniają się trzy rangowo najistotniejsze (incipitowe), duże inicjały o wysokości ośmiu wersów, umieszczone przed nieszporami w Godzৃin-

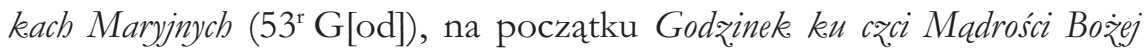
(69 ${ }^{\mathrm{r}} \mathrm{M}$ [yne]) oraz Godzinek ku cz̧ci Ducha św. (103 H[ere]; il. 4). Litery te, o dekoracyjnie rozciagniętych szeryfach, wyróżniają się uformowaniem lasek, podzielonych na kilka segmentów, $\mathrm{z}$ wmalowanymi w nie drobniejszymi motywami ornamentalnymi. Wyjątkowo w świetle inicjału $53^{\mathrm{r}}$ pojawia się motyw figuralny - hybryda o zielono-różowym ciele, wtulona w zielony pak (il. 7). Trudno orzec, czy wszystkie inicjały barwne wykonał ten sam dekorator, czy też pracowało przy nich dwóch iluminatorów, operujących indywidualnym wzornikiem. Wyraźne jest wprawdzie zgodne $z$ tradycyjna hierarchia dekoracji zamierzenie, by inicjały o złotych tłach rozpoczynały poszczególne godziny (a więc by pełniły funkcję znaczników), ale nie jest to reguła, gdyż grupa średnich inicjałów tego typu zastępuje czasem inicjały w ramce.

Tylko jeden inicjał w całym kodeksie $-12^{\mathrm{r}} \mathrm{H}[\mathrm{ere}]$, incipit Godzinek o Najśniętszej Marii Pannie - zdecydowanie wyróżnia się spośród pozostałych jako największy $(50 \times 57 \mathrm{~mm})$, mający rozbudowaną dekorację figuralną (il. 8). Jego struktura jest podobna do wyżej omówionych - litera o wydłużonych szeryfach i dzielonej na segmenty lasce jest umieszczona w czworokątnym polu, wypełnionym złotem i zdobionym rzadko rozmieszczonymi, tłoczonymi punkcikami. W świetle litery znajduje się przedstawienie Matki Bożej z Dzieciątkiem, osadzone w abstrakcyjnej przestrzeni (na złotym tle), której jedynym punktem odniesienia do rzeczywistości jest skrawek malachitowej zieleni (skałka?, łąka?), formujący siedzisko dla tronującej na nim postaci, ujętej en trois quarts do widza. Maria jest odziana w różową suknię o długich wąskich rękawach oraz w intensywnie błękitny płaszcz, otulający niemal cała jej sylwetkę. Dłu-

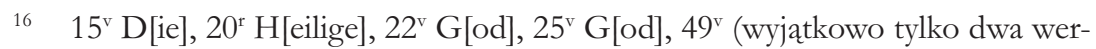
sy), $64^{\mathrm{v}}$ A[lle], $71^{\mathrm{r}} \mathrm{C}[$ omet]. 
gie, jasne włosy postaci, gładko zaczesane przy twarzy, opadają nisko na plecy. W wyciagniętych przed siebie ramionach Maria unosi Dzieciątko o sterczącej sztywno, jasnej czuprynce, zawinięte w biały becik, okręcony czerwoną tasiemka. Przedstawienie jest malowane dość schematycznie, bez dbałości o detal. Zasadnicze plamy barwne są dookreślone za pomocą zamaszystego konturu o jaśniejszym lub ciemniejszym odcieniu (biel i ciemny błękit na płaszczu, cynobrowa czerwień na sukni Marii, blada żółcień i ciemna zieleń w partii „łąki”).

\section{Bordiury}

$\mathrm{Na}$ marginesach aż 134 spośród 254 stronic kodeksu rozpościera się dekoracja roślinna, w której szczególną uwagę zwracaja motywy drolerie. Opatrzono nią karty początkowe godzin i ich części, a więc te, na których znajdują się omówione wyżej, gwaszowe inicjały, podczas gdy karty z tekstem ciagłym brewiarza są zupełnie pozbawione zdobień na marginesach (il. 5). Tylko 30 bordiur wykonano w całości (zob. il. 1-4, 7), inne są pozostawione na różnym etapie wykończenia. Nie zakłóca to jednak ogólnego oddziaływania modlitewnika, gdyż cała ta dekoracja ma ujednolicony charakter stylowy i musiała powstać jednocześnie. Kolejność wykańczania foliałów była poza tym konsekwentna i wynikała $z$ ich rangi. Dekoracja kart, wprowadzających do kolejnych części Godżinek i do poszczególnych godzin, została w większości ukończona w szczegółach ${ }^{17}$, podczas gdy na kartach, zawierających początki modlitw, bordiury są na ogół tylko z grubsza naszkicowane.

W koncepcji bordiur zwraca uwagę stosowanie dwóch typów kompozycji - wici roślinnej wokół trzech marginesów (52 stronice, przeważnie zawierające wejścia do godzin i psalmów ${ }^{18}$ ) oraz krótkich wypustek poziomych na górnym i dolnym marginesie (82 karty). W tej drugiej grupie żadna z kompozycji nie została ostatecznie wykończona (il. 9), choć o takim rach $95^{\mathrm{r}}$.

17 Wyjątkowo nie ukończono jedynie wici przy sekście $90^{\mathrm{v}}$, nonie $92^{\mathrm{r}}$ i nieszpo-

18 Tylko wyjątkowo bordiura zamyka się wokół całej kolumny tekstu, tak jest w przypadku kart $12^{\mathrm{r}}, 19^{\mathrm{r}}, 69^{\mathrm{r}}$. 
zamierzeniu pierwotnym świadcza foliae $4^{\mathrm{r}}$ (il. 6), $73^{\mathrm{v}}$ i $122^{\mathrm{v}}$ - rozpoczęto na nich nakładanie powierzchniowych szczegółów na listowie. Porównanie z północnoniderlandzkimi Godzinkami Katarzyny z Kleve ${ }^{19}$, w których zastosowano podobny system dekoracji, wskazuje, że rozpiętość wypustek, ograniczona tylko do części marginesów poziomych, była raczej zamierzona (czyli nie planowano zespolenia ich za pomocą dodatkowych ornamentów na marginesie pionowym).

Zasadą kompozycyjną wszystkich tych zdobień jest ujęcie kolumny tekstu w ramkę lub - w przypadku stronic $\mathrm{z}$ wypustkami - zaopatrzenie jej od zewnątrz w pionową listwę, spajająca górną i dolną partię ornamentu i „stabilizującą” optycznie wygląd karty. Ramki i listwy składają się z dwóch części - obwódki wewnętrznej, złotej, oraz zewnętrznej, podzielonej na błękitne i czerwone segmenty, dodatkowo ożywionej pojedynczą białą kreską. Niemal wszystkie bordiury i wypustki są skonstruowane z bujnej dekoracji akantowej, tworzącej sekwencje dużych, regularnych wolut $^{20}$. Wić jest zbudowana $\mathrm{z}$ mięsistego, strzępiastego listowia $\mathrm{w}$ kilku zasadniczych barwach (róż, złoto i błękit, sporadycznie zieleń malachitowa, najrzadziej czerwień cynobrowa), któremu nadawano przestrzenność, operując różnym natężeniem waloru. Liście były wykańczane czarnym, nie zawsze regularnym konturem i drobnym białym perełkowaniem w partii grzbietów. Często w obręb wici wplatano wydłużone szyszki (na ogół umieszczone w narożach, ale czasem także w centrum pionowego marginesu) i drobniejsze strączki w jaskrawych barwach.

W ukończonych przykładach pomiędzy pędy akantu wprowadzono drobne wykończenie tła roślinnymi ornamentami. Trudno określić, czy z równą drobiazgowością miały zostać dopracowane wszystkie naszki-

19 Nowy Jork, Pierpont Morgan Library, MSS M. 917, np. f. 11 ${ }^{\mathrm{r}}, 231^{\mathrm{v}}, 233^{\mathrm{r}}, 352^{\mathrm{r}}$. Zob. reprodukcje m.in. w: The Hours of Catharine of Cleves, introd. and commentaries by J. Plummer, New York 1966, oraz Das Stundenbuch von Katharine von Kleve. Anlässlich der Ausstellung die Welt der Katharina. Frömmigkeit, Dämonen und Alltägliches Leben im 15. Jahrbundert, Museum Het Valkhof, Nijmegen, 10. Oktober 2009-4. Januar 2010, The Morgan Library \& Museum, New York, 22. Januar-3. Mai 2010, hrsg. von A. M. W. As-Vijvers, Stuttgart 2009. Godzinki są też dostępne online: http://www.themorgan.org/collections/works/cleves/manuscript.asp.

20 Sporadycznie pojawia się motyw dodatkowej listwy, wokół której są skomponowane woluty $-108^{v}$. 
cowane kompozycje, jako że w niektórych układ wolut akantowych jest dość gęsty. Owo wykończenie tła ma dwa zasadnicze warianty. W czternastu ukończonych przykładach pojawia się delikatna wić z zielonych łodyżek (np. 19 $, 40^{\mathrm{r}}, 69^{\mathrm{r}}$; zob. il. 3), czasem zakończonych niewielkimi kwiatami ostu (il. 7). W drugim podtypie (osiem ukończonych kompozycji) spoiwo tła stanowi drobny, czarny ornament piórkowy (np. $15^{\mathrm{v}}, 21^{\mathrm{r}}$, 44; zob. il. 2), jaki pewnie z powodzeniem można byłoby wprowadzić także pomiędzy gęściej ułożone pędy (il. 10). Całość jest wzbogacona o drobne, złote ziarenka we włosowej otulinie oraz motywy figuralnej drolerie, której zarysy występują też na bordiurach nieukończonych. Wśród powtarzalnych motywów zoomorficznych pojawiają się: paw $\left(20^{\mathrm{r}}\right.$, $\left.25^{\mathrm{r}}\right)$, żuraw lub czapla $\left(11^{\mathrm{r}}, 23^{\mathrm{r}}, 40^{\mathrm{r}}, 61^{\mathrm{r}}, 70^{\mathrm{r}}\right)$, rajski ptak $\left(34^{\mathrm{r}}, 40^{\mathrm{r}}\right)$, pies $\left(20^{\mathrm{r}}, 48^{\mathrm{v}}\right)$, niedźwiedź $\left(40^{\mathrm{r}}, 86^{\mathrm{v}}\right)$, jeleń $\left(59^{\mathrm{r}}, 67^{\mathrm{r}}, 73^{\mathrm{v}}\right)$, zając $\left(48^{\mathrm{r}}\right)$, małpa $\left(4^{\mathrm{r}}\right.$, $\left.126^{\mathrm{r}}\right)$, lew $\left(69^{\mathrm{r}}\right)$, jednorożec $\left(26^{\mathrm{r}}\right)$, hybryda zoomorficzna $\left(20^{\mathrm{r}}, 95^{\mathrm{r}}, 98^{\mathrm{r}}\right)$, hybryda z ludzka twarza $\left(39^{\mathrm{r}}\right)$, smok $\left(59^{\mathrm{r}}, 89^{\mathrm{r}}, 90^{\mathrm{v}}, 115^{\mathrm{v}}\right)$. Występują także postaci ludzkie: niedźwiednik $\left(40^{\mathrm{r}}\right)$, jeździec dosiadający smoka $\left(115^{\mathrm{v}}\right)$, poganin lub dziki mąż $\left(86^{v}\right)$, aniołowie $\left(98^{v}, 108^{v}\right)$. Motywy te albo sa malowane monochromatycznie (także w ukończonych kompozycjach), albo też - jak ptaki w partii Godzinek o NMP - cechuja się bajecznym zestawem wielu kontrastowych barw.

Obok tego przeważającego schematu zdobień mamy ponadto do czynienia z kilkoma kartami, których dekoracja odbiega od opisanej zasady, cechując się przy tym nieco chłodniejsza, zgaszoną kolorystyką. Występują one zwłaszcza w obrębie księgi Godz̨inek o Duchu św. i określaja początki kolejnych godzin kanonicznych. Zamiast liści akantu pojawia się tutaj regularna wić winnej latorośli, opleciona wokół dodatkowej, prostej ramki, umieszczonej w pewnej odległości od lustra tekstu (il. 4). W sploty latorośli są najczęściej wkomponowane półpostaci długowłosych aniołów w złotych nimbach, o długich, dwubarwnych skrzydłach, wyłaniające się ze schematycznych obłoków. Odziani w luźne tunicae manicatae o zróżnicowanych barwach (różne odcienie ugru, róż, intensywny błękit), aniołowie wykonuja gesty modlitewne, rzadziej - muzykują $\left(103^{r}\right)$ lub dłońmi wskazują w stronę lustra tekstu, pośrednicząc w jego percepcji $\left(88^{\mathrm{r}}\right.$, $\left.108^{v}, 119^{v}\right)$. Niekiedy pojawiają się postaci serafinów, nieco „figlarnie” owijających skrzydła o ramę $\left(103^{\mathrm{r}}\right)$, w niektóre kompozycje są dodatkowo wprowadzone przedstawienia niedźwiedzi $\left(33^{\mathrm{r}}, 103^{\mathrm{r}}, 123^{\mathrm{r}}\right)$. Na folio $116^{\mathrm{r}}$ 
w pędach latorośli pojawiają się dwa niedźwiedzie, zoomorficzna hybryda oraz małpka.

$\mathrm{Na}$ tle ogółu zdobień wyróżnia się incipitowa karta $12^{\mathrm{r}} \mathrm{z}$ inicjałem figuralnym (il. 1), poprzedzona zapewne niegdyś kartą z miniaturą figuralną. Ornamentalna bordiura otacza tu ze wszystkich stron lustro tekstu, ujęte niegdyś w złoconą listwę (dziś silnie przetarta). Bordiura cechuje się tu zadrobnieniem motywów i swobodą kompozycji, w której dominująca rola przypada gałazkom, malowanym zielenią o odcieniu malachitowym, zakończonym drobnymi pączkami, kwiatami lub owocami o różnej barwie. Te mało giętkie pędy wyrastają z dwubarwnych, wąskich, sprężystych liści akantu, malowanych błękitem, różem oraz sproszkowanym złotem. Ich wykończenie różni się od wykończenia ornamentów na innych kartach - zamiast drobnych białych perełkowań pojawia się tu regularna cienka linia, znacząca zasadniczy dukt użylenia liści. Tak uformowana wić układa się na zewnętrznych marginesach w podwójne symetryczne palmety (na wewnętrznym marginesie dekorację tworzą jedynie pojedyncze, wydłużone liście). W tle, pomiędzy tym luźno rozrzuconym wzorem, znajdują się równomiernie rozmieszczone, złote ziarenka w oszczędnej włosowej otulinie (w dużej mierze zachował się tylko pulment, złoto uległo wytarciu).

\section{Proweniencja}

Droga toruńskiego kodeksu 83 na Pomorze Wschodnie nie jest znana, choć należałoby raczej wykluczyć powstanie Godzinek w lokalnym środowisku, proponowane swego czasu przez Alicję Karłowską-Kamzowa, opierającą się na wrażeniu „pogrubienia motywów” w stosunku do wzorców niderlandzkich, które badaczka najogólniej przytoczyła ${ }^{21}$. Tymczasem niderlandzka proweniencja tekstu modlitw i język kodeksu (wschodnio-

21 A. Karłowska-Kamzowa, Dekoracje malarskie, s. 142: autorka przywołała analogie w szeregu kodeksów z pierwszej połowy XV w., o proweniencji zarówno południowo-, jak i północnoniderlandzkiej, wskazując na zbliżone typy twarzy, floratury z motywami zoomorficznymi, półfigury aniołów na marginesach. Zestawienie tych motywów w manuskrypcie toruńskim uznała jednak - chyba niesłusznie - za kompilacyjne, a opracowanie malarskie za pozbawione finezji i biegłości. W późniejszej publikacji umieściła modlitewnik w rozdziale poświęconym produkcji lokalnej, uwa- 
dolnoniderlandzki ${ }^{22} \mathrm{z}$ wtrętami łacińskimi), a także obserwacje Päslera, dotyczące kalendarza diecezji utrechckiej ${ }^{23}$, pozwalają uważniej przyjrzeć się możliwości sprowadzenia kodeksu z Niderlandów Północnych.

Najbardziej podstawowa cecha zdobień kodeksu - typ i wykończenie akantu - opiera się wprawdzie na popularnym w XV wieku modelu, stosowanym dość szeroko przez późnośredniowiecznych iluminatorów i znanym ze wzornika miniatorskiego z Getyngi z około $1450 \mathrm{roku}^{24}$. Niemniej jednak szereg cech szczegółowych dekoracji kodeksu 83, zarówno w koncepcji całościowej zdobień, jak i w poszczególnych elementach (typ inicjałów, typ motywów figuralnych), a przede wszystkim swobodny styl malarski potwierdzaja pochodzenie księgi z kręgu sztuki północnoniderlandzkiej, ogniskującej się wokół ośrodków w Gueldern i Utrechcie. Do tamtejszej tradycji - zwłaszcza do doświadczeń pierwszej generacji iluminatorów utrechckich (1420-1430) - wydaje się nawiązywać przede wszystkim styl przedstawień figuralnych. Schematyczna, jakby pospieszna maniera malarska, intensywna kolorystyka, typ postaci ludzkich o dużych, lekko wydłużonych głowach, grubych szyjach i drobnych dłoniach, sumaryczny modelunek draperii - są utrzymane w konwencji tzw. Mistrzów Ottona van Moerdrecht. To zwyczajowe pojęcie, pod którym kryje się większa grupa dekoratorów, zostało ukute od manuskryptu, zleconego przez ka-

żając go - mimo inspiracji niderlandzkich - za różny od dzieł tamtego środowiska: eadem, Środowiska miejscowe, s. 216.

22 Identyfikacja języka za R. G. Päsler, Katalog der mittelalterlichen, s. 193. Godżinki w tłumaczeniu Grootego to standard wśród holenderskich modlitewników prywatnych, zob. R. G. Calkins, Distribution of Labor: The Illuminators of the Hours of Catherine of Cleves and Their Workshop (Transactions of the American Philosophical Society, New Series, vol. 69, no. 5), Philadelphia 1979, s. 5.

23 R. G. Päsler przyjmuje za prawdopodobne miejsce powstania w Utrechcie, idem, Katalog der mittelalterlichen, s. 193.

24 Wzornik ten, rejestrujący starszą tradycję miniatorska, powstał w Moguncji w dobie prężnego rozkwitu tamtejszej produkcji miniatorskiej i dostarcza dokładnych informacji o stosowanej przez dekoratorów metodzie postępowania. H. Lehmann-Haupt, Introduction, [w:] The Göttingen model book. A facsimile edition and translations of a fifteenth-century illuminators manual, ed. with commentary by H. Lehmann-Haupt, based in part on the studies of E. Will, Columbia 1972, s. 18. 
nonika utrechckiego, Ottona Meliszoona van Moerdrecht w $1424 \mathrm{roku}^{25}$, przy czym utrechcka geneza tego nurtu nie jest pewna ${ }^{26}$. Do najważniejszych dzieł, wykonanych w tym charakterystycznym stylu, należy m.in. druga część słynnych Godzinek Marii de Gueldern²7, grupa wielkich Biblii, zwłaszcza haska Biblia Historiale ${ }^{28}$ - częściowo dzieło tzw. Mistrza D, a także partia Godzinek Egmonta ${ }^{29}$ i szereg innych brewiarzy prywatnych ${ }^{30}$.

25 N. de Lyra, Postilla in prophetas, 1423-1425, Utrecht - Universiteitsbibliotheek, Ms. 252. Zob. H. M. Defoer, A. S. Korteweg, W. C. M. Wüstefeld, The Golden Age of Dutch Manuscript Painting, introd. J. H. Marrow, cart. Rijskmuseum het Catharijneconvent, Utrecht-the Pierpont Morgan Library, New York-Stuttgart-Zürich 1989, nr kat. 21, s. 78-80.

26 A. V. Byvanck uważał, że „Mistrz Ottona van Moerdrecht”, którego identyfikował z jednym tylko dekoratorem, pracował w skryptorium kartuzji Nieuwlicht w Utrechcie. Zob. m.in. A. V. Byvanck, La miniature dans les Pays-Bas septentrionaux, Paris 1937, s. 41-45 (zwł. s. 44). Ustalona przez tego autora geneza stylu funkcjonowała w badaniach przez dłuższy czas, co zostało jednak podważone w nowszej literaturze, zob. H. M. Defoer, A. S. Korteweg, W. C. M. Wüstefeld, op. cit., s. 77-78.

27 Godzinki Marii de Gueldern, Staatsbibliothek Berlin, MS germ. Q.42, Mistrz Marii de Gueldern - 1415, kodeks rozszerzony o karty 425 $-482^{\mathrm{v}}$, dekorowane przez Mistrzów Ottona van Moerdrecht w latach 1423-1425. H. M. Defoer, A. S. Korteweg, W. C. M. Wüstefeld, op. cit., nr kat. 17, s. 67-70.

28 Biblia historiale, Koninklijke Bibliotheek w Hadze, The Hague KB, 78 D38 I, reprod. online: http://www.kb.nl/manuscripts/show/images/78+D+38+I. Zob. również A. V. Byvanck, op. cit., s. 31-34; H. M. Defoer, A. S. Korteweg, W. C. M. Wüstefeld, op. cit., nr kat. 38, s. 113-135. Kodeks Biblii był dekorowany także przez innych iluminatorów - Mistrza Claesa Brouwera, Mistrza Psałterza, Mistrza Azora, mistrza F i Mistrza Gethsemani.

29 Brewiarz Egmonta (należący do księcia Arnolda van Egmont, a później w rękach biskupa utrechckiego, Georga van Egmont), ok. 1425-1435, Pierpont Morgan Library w Nowym Jorku, Ms. M.87. Zdobienia manuskryptu sa przypisywane utrechckim twórcom: Mistrzom Ottona van Moerdrecht, Mistrzowi God₹inek Katarzyny z Kleve i Mistrzowi Zwedera van Culemborg. A. V. Byvanck, op. cit., s. 149-150; H. M. Defoer, A. S. Korteweg, W. C. M. Wüstefeld, op. cit., nr kat. 36, s. 112-115.

30 Przykładowo: The Hague KB, 135 K11, reprod. online: http://www.kb.nl/ /manuscripts/show/images/135+K+11; The Hague KB, 135 K45, reprod. online: http://www.kb.nl/manuscripts/show/images/135+K+45, a także Godzinki przypisywane naśladowcy Mistrzów Ottona van Moerdrecht (The Hague KB, $135 \mathrm{~J}$ 50, f $14^{v}$, reprod. online: http://www.kb.nl/manuscripts/show/images/135+J+50). 
W zespole tym znajdujemy liczne analogie do dekoracji manuskryptu toruńskiego, szczególnie dla przedstawienia Madonny w inicjale na folio $12^{\mathrm{r}}$.

Kompozycjom z kręgu utrechckiego bliskie jest sztywne, półprofilowe ujęcie postaci Marii, jej oszczędna gestykulacja, jak również pociagła, płasko malowana twarz o sumarycznie zasygnalizowanych rysach, kładzionych za pomocą drobnych pociagnięć pędzelka ${ }^{31}$. Bliskie podobieństwo znajdujemy przykładowo w miniaturze na f. $19^{\mathrm{v}}$ w Godzinkach KB 135 K45. Ukazuje ona tronującą Madonnę ujętą en trois quarts, o bardzo zbliżonych proporcjach ciała i rysach twarzy, spowita w błękitny płaszcz, opadający płaskimi, sztywnymi fałdami ku dołowi, trzymająca przed soba Dzieciątko o nastroszonej falistej czuprynce (analogie do tego ostatniego motywu znajdujemy także w innych kodeksach „Mistrzów Ottona van Moerdrecht"32). Do wzorców z kręgu utrechckiego - zwłaszcza do wspomnianej Biblii Historiale KB 78 D38 I - nawiązuje przedstawienie postaci niedźwiednika na folio $40^{\mathrm{r}}$ (il. 11) ) $^{33}$ oraz sposób ujęcia półfigur anielskich (il. 12), w tym tak drobny szczegól, jak sterczące skrzydła, których grzbiety naznacza białe perełkowanie ${ }^{34}$.

Wskazane zbieżności stylistyczne potwierdza analiza pozostałych partii dekoracji modlitewnika 83. Częstokroć w kręgu północnoniderlandzkim natrafiamy na typ inicjału, w którym litera jest wpisana w złote tło o nieregularnym wykroju z półkolistymi wcięciami i zdobiona biała dekoracją w formie dwóch lub trzech segmentów z czwórliśćmi w lasce pionowej i motywu kwiatowego na brzuścu ${ }^{35}$. W przytoczonych dziełach

31 Zob. przykładowo miniaturę z Koronacja Marii na f. $467^{\mathrm{v}} \mathrm{w}$ Brewiarzu Marii de Gueldern (reprod. A. V. Byvanck, fig. 36-37) czy miniatury na f. 15ㄴ, 56, $181^{\mathrm{v}}$ w Godzinkach KB 135 K11.

32 Przykładowo na f. 216 przywołanych wyżej Godzinek KB 135 K11 - w scenie ze sw. Michatem Archaniołem zwracają uwage postaci na szalach wagi, o tak właśnie uformowanych włosach.

33 Półprofilowe ujęcie postaci niedźwiednika w spiczastej czapce, odzianego w luźną krótką opończę i nogawice typu chausses semelées, znajduje analogie w wyobrażeniach męskich w obrębie scen narracyjnych z historii Mojżesza i Jozuego na kartach Biblia Historiale KB, 78 D38 I: 129 ${ }^{\mathrm{r}}, 131^{\mathrm{v}}$, 132, $148^{\mathrm{r}}$.

34 Ibidem, f. $227^{\mathrm{r}}$.

35 Przykładowo w haskich Godzinkach (KB, 35 K11), inicjał M[yne] na f. 15", $\mathrm{H}[\mathrm{ere}] 130^{\mathrm{v}}, \mathrm{H}$ [ere] 181, i w Biblii Historiale KB, 78 D38 I. Dekorację taką znajdujemy 
ma również swe źródło koncepcja umieszczenia na złotym tle światła litery figur ludzkich, osadzonych na skrawku zieleni (np. w inicjałach haskiej Biblii Historiale KB 78 D38 I) ${ }^{36}$. Do schematów, stosowanych przez utrechckich iluminatorów, należy także zrealizowany w toruńskim kodeksie pomysł zakomponowania ornamentu roślinnego marginaliów wokół sztywnej listwy (rama lub pojedyncze pręty), optycznie stabilizującej wić3 ${ }^{37}$. Występujące w partii Godżinek o Duchu św. półpostaci aniołów w obrębie bordiur mają również północnoniderlandzką tradycję - znajdujemy je i u „Mistrzów Ottona van Moerdrecht”38, i w kręgu „Mistrzów Zwedera van Culemborg" "39, i - nieco później - u Mistrza Godżinek Katarayny z Kleve ${ }^{40}$. Nieobce jej były i inne motywy, zastosowane w toruńskim manuskrypcie. Na stylizowane szyszki natrafiamy w haskiej Biblii Historiale $e^{41}$, na zwierzęce drolerie (małpki, niedźwiadki, hybrydy, czaple) - w Godżinkach Katariyny z Kleve $e^{42}$.

$\mathrm{O}$ dokładnej proweniencji dzieła trudno jednak na tej podstawie zawyrokować, biorąc pod uwagę fakt, że styl malarski „Ottona van Mo-

też w inicjałach bifolio, przechowywanego w Museum Meyera van der Bergh w Antwerpii, MS, 302, f. CLXXXVIr i CLXXVII ${ }^{\mathrm{r}}$, reprod. w: H. M. Defoer, A. S. Korteweg, W. C. M. Wüstefeld, op. cit., pl. 24 oraz fig. 37 na s. 84. Ten typ inicjału pojawia się też we wspomnianych już, późniejszych Godzinkach Katarayny z Kleve (Nowy Jork, Pierpont Morgan Library MSS M. 917), np. 39 ${ }^{\mathrm{r}}, 62^{\mathrm{r}}, 65^{\mathrm{r}}, 117^{\mathrm{v}}$.

36 Ibidem, m.in.: $1^{\mathrm{r}}, 76^{\mathrm{r}}, 91^{\mathrm{r}}, 113^{\mathrm{v}}$.

37 Jako przykład można przywołać f. $14^{\mathrm{v}}$ z kodeksu KB, 135 J 50, oraz dzieło Mistrza Zwedera van Culemborg (The Hague KB, $79 \mathrm{~K} \mathrm{2,} \mathrm{f} 70^{\mathrm{v}}-71^{\mathrm{r}}$, reprod.: A. Byvanck, op. cit., fig. 99, oraz online: http://www.kb.nl/manuscripts/show/ images $/ 79+\mathrm{K}+2$ )

38 Na przykład przywołane wyżej Godżinki z Królewskiej Biblioteki w Hadze $79 \mathrm{~K} 2$ (f. $\left.12^{\mathrm{r}}, 27^{\mathrm{v}}, 28^{\mathrm{r}}, 71^{\mathrm{r}}\right)$ oraz $135 \mathrm{~J} 50\left(15^{\mathrm{r}}, 41^{\mathrm{v}}\right)$.

39 Przykładowo Godzinki z prywatnej kolekcji we Francji, 1425-1430, f. 83르, $119^{r}$, reprod. w: H. M. Defoer, A. S. Korteweg, W. C. M. Wüstefeld, op. cit., pl. 31, fig. 46 na s. 104; Godzinki w prywatnej kolekcji w USA, ok. 1430, f. 85-86 , pl. 34; Godzinki w Walters Art Galery w Baltimore, MS. W. 168, f. 85v , 166v, reprod. w: ibidem, pl. 37, fig. 55 na s. 116.

40 Brewiarz Egmonta, Pierpont Morgan Library w Nowym Jorku, Ms. M. 87, f. 387v. Reprod. w: A. Byvanck, op. cit., s. 149-150, fig. 44.

41 Biblia Historiale KB, 78 D38 I, 46.

42 Pierpont Morgan Library w Nowym Jorku, MSS M. 917, np. 61 $, 64^{\mathrm{r}}, 83^{\mathrm{v}}$, $90^{\mathrm{r}}$. 
erdrecht" był reprezentowany przez większą liczbę twórców i ich naśladowców, cieszył się dużą popularnością w latach około 1430-1450, a w połowie stulecia został zaadaptowany przez iluminatorów, pracujacych w różnych ośrodkach Niderlandów Północnych i Brabancji ${ }^{43}$. Pojawiał się w manuskryptach, w których mieszały się style różnych ośrodków północnoniderlandzkich ${ }^{44}$, a także w kodeksach, wykonywanych w Niderlandach Południowych ${ }^{45}$. Przytoczone analogie wskazuja jednak z dużym prawdopodobieństwem, że warsztat, który ozdobił toruński kodeks 83, wyniósł swą formację artystyczna z kręgu „Mistrzów Ottona van Moerdrecht”. Datowanie dzieła toruńskiego, ustalone przez Alicję Karłowska-Kamzową na przełom XV i XVI wieku ${ }^{46}$, można więc przesunać wstecz, ku połowie - jeśli nie ku drugiej ćwierci - XV stulecia.

Osobnym problemem, związanym z kodeksem 83 , jest próba uściślenia podziału pracy w obrębie warsztatu, również podjęta swego czasu przez Karłowską-Kamzowa. Jej zdaniem różnice w podejściu do struktury dekoracji marginalnych wskazują, że nad rękopisem pracowało dwóch dekoratorów, z których pierwszy miałby być autorem kart z bordiurami

43 H. M. Defoer, A. S. Korteweg, W. C. M. Wüstefeld, op. cit., s. 77-78.

44 Przykładem może być psałterz Bouta w Hadze (The Hague, KB, 79 K11), dzieło wielu rąk o różnej formacji (Utrecht, Haarlem, Amsterdam) z ok. 1453 r. Zob. informacje na temat pozyskania dzieła dla Biblioteki Haskiej na stronie web-exhibitions: http://www.kb.nl/bladerboek/bout/index-en.html. Dekoracja dwu kart tego manuskryptu - f. 61 ${ }^{\mathrm{v}}$ i f. 79 - wyszła spod ręki któregoś z Mistrzów Ottona van Moerdrecht i - zwłaszcza w partii bordiur - przypomina iluminacje kodeksu toruńskiego. Wić roślinna o wyciagniętych, suchych łodygach przypomina bordiurę z f. $12^{\mathrm{r}}$, zbliżone są także półpostaci aniołów w różowych szatach. Uderzające analogie wykazuje też dość wąska, ciepła gama barwna, przy czym styl dekoracji Psałterza Bouta wydaje się silniej zmanierowany.

45 Przykładem może być kodeks naśladowcy stylu Mistrzów Ottona van Moerdrecht, tzw. Mistrza Petera Danielssoena z 1457 r. w Museum voor Religiouze Kunst w Uden, MS. BM 400. Godzinki te zostały wykonane w Niderlandach południowych: M. Defoer, A. S. Korteweg, W. C. M. Wüstefeld, op. cit., nr kat. 26, s. 87, pl. 26. Warto nadmienić także o praktyce znakowania miniatur w stylu utrechckim, wykonanych w Brugii, jaka została wprowadzona nakazem Rady Miejskiej w Brugii w 1427 r. i jest poświadczona we wspomnianych już Godzinkach, przechowywanych w Hadze, KB 135 K 45, dekorowanych przez jednego z Mistrzów Ottona van Moerdrecht.

46 A. Karłowska-Kamzowa, Środowiska miejscowe, s. 216. 
akantowymi i ze świeckimi motywami figuralnymi, a drugi - kart z winną latoroślą $\mathrm{i}$ aniołami ${ }^{47}$. Przy wnikliwszym oglądzie wydaje się jednak, że miniatury te różnią się przede wszystkim koncepcją kompozycyjna, a nie ręka mistrza - ich wprowadzenie do kodeksu wiązało się być może ze strukturą samego tekstu. Motyw ptaków występuje głównie w części Godzinek o NMP, podczas gdy na postaci aniołów natrafiamy w dwóch pozostałych partiach modlitw, przy czym winna latorośl przeważa w Godzinkach o Duchu sw. Dyspozycja ta nie była jednak ściśle przestrzegana, gdyż schemat z winną latoroślą można sporadycznie znaleźć także we wcześniejszych częściach rękopisu, np. na kartach $33^{\mathrm{r}}$ czy $88^{\mathrm{r}}$. W obrębie całego kodeksu jest też zauważalna wymienność motywów, jak na przykład wprowadzenie dodatkowej listwy i półpostaci anielskich w wić akantowa (92v, 98v). Poza tym niepełne wykończenie modlitewnika umożliwia wnikliwą obserwację porównawcza poszczególnych kart pod kątem techniki i metody wykonania. Wskazuje ona, że z góry zaplanowaną dekorację (zasadnicze układy kompozycyjne, dostosowane do konkretnych partii tekstu) tworzono mniej lub bardziej współzależnymi od siebie etapami, których kolejność nie zawsze była ściśle przestrzegana - co sugeruje dużo bardziej złożony podział pracy i jej „taśmowa” organizację w obrębie warsztatu ${ }^{48}$.

\section{Analiza metody twórczej warsztatu Godzinek 83}

Pierwszy etap dekorowania stronicy rękopisu, po ukończeniu tekstu na luźnych arkuszach, stanowiło wprowadzenie inicjałów kaligraficznych w pozostawione przez skryptora miejsca. Dotyczyło to szczególnie inicjałów najdrobniejszych, ale można przyjąć, że wszystkie inicjały w księdze (z wyjątkiem drobnych inicjałów złotych, które być może dodano na późniejszym etapie) były najpierw kreślone kaligraficznie błękitnym inkaustem. Większe litery zaopatrywano często w filigran, określający ich

47 Eadem, Dekoracje malarskie, s. 139.

48 Na temat podziału pracy w warsztatach średniowiecznych zob. m.in. B. Miodońska, Organizacja i technika pracy iluminatorów matopolskich w latach 1400-1520, [w:] Symbolae historiae artium. Studia ₹ historii sztuki Lechowi Kalinowskiemu dedykowane, pod red. J. Gadomskiego, Warszawa 1986, s. 329-347. 
zasadnicze pola ${ }^{49}$, i wyprowadzano $z$ nich niciowe wypustki ${ }^{50}$. Analiza porównawcza wypustek, występujących przy różnych typach inicjałów w kodeksie, wskazuje, że wszystkie wykonał ten sam dekorator (być może sam skryba), nadając podobny rozmach zarówno wypustkom u większych, jak i u najdrobniejszych liter. Realizował on chyba swe zadanie, nieświadom całościowej koncepcji wykończenia, jakie miało być docelowo nadane rękopisowi. Swobodnie kreślone wypustki mają wprawdzie szczególne znaczenie estetyczne w przypadku kart zupełnie pozbawionych roślinnych bordiur, gdzie towarzysza z reguły jednowersowym inicjałkom (il. 5). W wielu miejscach jednak jego ornamenty zostały w dużej mierze przysłonięte dekoracją roślinną (powodując wrażenie optycznego nieładu, np. $12^{v}$ ), a wszystkie większe inicjały kaligraficzne zakryto inicjałami gwaszowymi, które często wkraczają na lustro tekstu (il. 9).

Najprawdopodobniej wstępnym etapem projektowania dalszej dekoracji było naniesienie ugrowym konturem ogólnego zasięgu zdobienia bordiur. Określano w ten sposób dyspozycję poszczególnych elementów - obramienie tekstu, umiejscowienie postaci drolerie ${ }^{51}$, rozmieszczenie złotych ziaren. Pierwotne obramienia są wciąż widoczne przykładowo na f. $88^{\mathrm{r}}, 119^{\mathrm{v}}, 129^{\mathrm{r}}$; na karcie $90^{\mathrm{v}}$ liściaste woluty wyraźnie są oparte na tym szkicu, podczas gdy barwną listwę obramienia naniesiono później, nie wszędzie go zakrywając. Ślady projektu nieukończonych złotych ziarenek zachowały się tylko sporadycznie ${ }^{52}$ (il. 13). Liczniej pozostawiono natomiast niewykończone motywy figuralne - anioły, zwierzęta i fantastyczne stworzenia (il. 14). Szkice te, nanoszone przez wprawnego iluminatora, cechują się sprężysta, pewną kreska, która dodatkowo bywała „podbijana” bardziej zamaszystą i grubszą linią o zielonkawym odcieniu lub podcienio-

49 Nie we wszystkich przypadkach można tę praktykę zaobserwować gołym okiem, ale w niektórych miejscach pod inicjałami malowanymi kryjąco czytelne są głębsze warstwy, np. na folio $23^{\mathrm{v}}$ i $109^{\mathrm{v}}$ spod inicjału barwnego wystaje szeryf błękitnej litery w cynobrowym obramieniu, a na folio $12^{\mathrm{v}}, 117^{\mathrm{r}}, 122^{\mathrm{v}}$ czy $124^{\mathrm{r}}$ wcięcia tła ukazują wyraźnie filigranowy kontur, leżący pod spodem.

50 Przykładowo: $1^{\mathrm{r}}, 3^{\mathrm{r}}, 91^{\mathrm{r}}, 96^{\mathrm{r}}, 99^{\mathrm{v}}, 100^{\mathrm{r}}, 103^{\mathrm{v}}, 109^{\mathrm{v}}$. Nie była to reguła, wiele kart z dużymi inicjałami jest pozbawionych wypustek.

51 Wyjątkowo na karcie $48^{v}$ szkic postaci charta wykonano czarnym inkaustem.

52 Drobne kółeczka, stanowiące szkic pod złote ziarenka, występują z rzadka (np. $\left.95^{\mathrm{r}}, 96^{\mathrm{r}}, 101^{\mathrm{v}}, 126^{\mathrm{r}}\right)$. 
wana (il. 15) ${ }^{53}$. Na niektórych nieukończonych kartach znajdujemy miejsca, gdzie taki szkic jest niemal w całości przykryty nieukończonymi liśćmi akantu $\left(59^{\mathrm{r}}, 67^{\mathrm{r}}, 68^{\mathrm{r}}, 73^{\mathrm{v}}\right)$. Zapewne na tym etapie pracy malowano także drugą ramę w kompozycjach z winną latoroślą i z rzadka - w kompozycjach $\mathrm{z}$ akantem - pozostawiając miejsce na postaci aniołów (przykładowo na karcie $98^{\mathrm{v}}$ dukt listowia jest przy ramce przerwany lub też liście na ramkę nachodza).

Następnie wprowadzano barwny rzut wolut akantowych, malowany bez rysunku przygotowawczego. Ponieważ w różnych częściach kodeksu gęstość wolut, ich rozłożystość, a także krój samych liści nieznacznie się różnicuja, przy nanoszeniu tej dekoracji mogła pracować większa grupa dekoratorów. Metoda była jednak w całym manuskrypcie analogiczna. Liście nanoszono w regularnej sekwencji kolorystycznej - różu, proszkowego złota oraz błękitu, dużo rzadziej sięgano dodatkowo po zieleń ${ }^{54}$ lub czerwień $\left(69^{\mathrm{r}}\right)$. Zasadnicze kontury i użylenia liści podkreślano ciemniejszym walorem tej samej barwy (w przypadku złota kładziono kreskę ugrową lub czarna). Jak się wydaje, jeżeli planowano wplecenie w wić drobnych strączków i pakków, były one malowane równocześnie z listowiem, gdyż często się z nim przenikają. Następnie, za pomocą różnych barw kryjących, wmalowywano zarysy szyszek (il. 16). Na ogól jądro jaskrawo ugrowe otaczano błękitną otulina, a jądro malachitowe - różową ${ }^{55}$. Wreszcie nakładano czarne obwódki w niektóre partie listowia (np. $70^{\mathrm{r}}, 76^{\mathrm{v}}, 84^{\mathrm{v}}$, $\left.106^{\mathrm{r}}\right)$, a rzadziej również - szyszek $\left(68^{\mathrm{r}}, 71^{\mathrm{r}}\right)$, oraz wykonywano walorowo malowane kontury jąder szyszek ${ }^{56}$.

Wydaje się, że dopiero po naniesieniu zarysu listowia (jeszcze bez białych perełkowań) wprowadzono na wszystkich arkuszach gwaszowe inicjały oraz ramki bądź pionowe listwy przy kolumnie tekstu. Wskazuje na to fakt, że krawędzie inicjałów i kontury ramek nakładają się na floratury. Pracę na tym etapie rozpoczynano od naniesienia złoceń z płatka na bia-

53 Na przykład $73^{\mathrm{v}}$.

54 W quaternionie $27^{\mathrm{r}}-34^{\mathrm{v}}$ zwraca uwagę, że w dekoracji dwóch bifoliae konsekwentnie występuje liść akantu w barwie zielonej; malachitowe liście znajdujemy też na folio $74^{\mathrm{r}}$.

55 Na przykład nieukończone karty $45^{\mathrm{r}}, 79^{\mathrm{v}}, 82^{\mathrm{r}}$.

56 Są one gotowe na kartach, na których nie ma jeszcze białych perełkowań. 
łym pulmencie. W ten sposób zostały wykonane pola złotych inicjałów ${ }^{57}$, bloki liter inicjałów barwnych oraz ramki (listwy) wewnętrzne. Była to typowa kolejność w średniowiecznym warsztacie ${ }^{58}$, a świadczą o niej liczne miejsca, w których warstwa malarska inicjałów nachodzi na złocenia. Być może na tym etapie „rzucano” na marginesy drobne ziarenka lub trójlistki ${ }^{59}$, choć - jak już wspomniano - nie wszędzie nakreślone wcześniej projekty ziaren zostały zrealizowane. Następnie wprowadzano segmentowe obramienia oraz barwne elementy inicjałów (tła przy literach złotych oraz wypełnienia bloku liter przy inicjałach o złotych polach). Podział pracy pomiędzy dekoratorami inicjałów mógł polegać na traktowanym jako specjalność nakładaniu płatków złota i wypełnianiu farbami. Ostatnia czynność przy inicjałach i ramkach stanowiło powierzchniowe wykończenie biała farba (włosowe linie, ornamenty w tłach, kreskowane „cienie” w korpusach liter) oraz okonturowanie pól inicjałów i zewnętrznej listwy za pomocą cienkiej czarnej kreski.

Ponieważ w całym kodeksie ramki, listwy i barwne inicjały zostały wykończone w jednakowym stopniu, można przypuszczać, że ten etap pracy objął jednocześnie większość arkuszy ${ }^{60}$, dzięki czemu nadano książce dość ujednolicony charakter. Najprawdopodobniej dopiero po tej czynności nastapiło odejście od zamiaru dalszego, spójnego wykończenia kart. Kolejne etapy wykonania dekoracji bordiur nie są już tak wyraźnie czytelne. Najpewniej kilku twórców pracowało równocześnie nad wykończeniem różnych elementów owego naniesionego z grubsza, malarskiego systemu.

Do etapu wykończenia należała praca nad szkicowanymi uprzednio postaciami drolerie (na f. $126^{\mathrm{r}}$ znajdujemy ukończone motywy figuralne, wprowadzone w naszkicowaną tylko akantowa bordiurę o pustym tle; il. 17). Postaci były przeważnie wypełniane płasko proszkowym złotem

57 Złocono tła w całości, bez pozostawiania miejsca pod literę, o czym przekonuja przetarcia farby liter, np. $103^{\mathrm{r}}$.

58 J. J. G. Alexander, op. cit., s. 40.

$59 \quad 29^{\mathrm{r}}, 31^{\mathrm{r}}, 93^{\mathrm{r}}$ nie ma szczegółów liści, a pojawiają się ziarenka; na folio $90^{\mathrm{v}}$ mają już one nawet otulinę, podczas gdy postać hybrydy pozostaje tam jeszcze w fazie szkicu. Także i od tej zasady są odstępstwa - na folio $95^{\mathrm{r}}$ hybryda jest już wypełniona kolorem, a nieukończone ziarenka pozostawiono na etapie ugrowego konturu.

${ }^{60}$ Taki mechaniczny sposób nakładania wykończeń tego samego typu jednocześnie w całym kodeksie poświadczają badania J. J. G. Alexandra, op. cit., s. 47. 
(np. jelonek na folio $63^{v}$ ), złamana zielenią lub szarościa (f. 108 $)$, w przypadku postaci rajskich ptaków posługiwano się także innymi barwami podkładu (il. 13, 18). Następnie nanoszono niektóre szczegóły przedstawień, np. pospiesznie malowane białe piórka (il. 13), kontury walorowe (np. pies na f. 53 $3^{\mathrm{r}}$, niedźwiedź na f. 40 ną linią (zob. il. 18-19), często nerwowo „rozedrganą” (il. 20). Miała ona szczególne znaczenie modelujące dla elementów wypełnianych proszkowym złotem.

Kolejny etap pracy stanowiło nadanie ostatecznego poloru akantom - wmalowywano powierzchniowe szczegóły szyszek, pąków i strączków, a następnie nanoszono na nie oraz na grzbiety liści szeregi białych pere$\ell \mathrm{k}^{61}$. Zapewne równocześnie podkreślano też bielą kontury liści i niektórych kwiatonów. Ostatnią czynnościa - niewykonaną niestety na większości zachowanych foliałów - było wypełnienie pustych przestrzeni tła zielonymi łodyżkami oraz wprowadzenie dekoracji piórkowej. Uzupełniano nią bordiury przez dołożenie drobnych zwiniętych gałązek do głównej wici (il. 21) oraz promyków wokół złotych ziaren i wąsów przy szyszkach. W drugim typie bordiur, pozbawionym linearnej wici roślinnej, piórkowa „pajęczynka” całkowicie wypełnia przestrzenie pomiędzy liśćmi akantu (il. 18).

Wydaje się, że dopiero po zakończeniu równomiernego wypełniania tła dopracowywano ostatecznie wielobarwne przedstawienia zwierząt, zaznaczając najdrobniejsze szczegóły (np. barwne piórka czy kropeczki jak u ptaka na folio $81^{\mathrm{v}}$ ). $\mathrm{Na}$ f. $61^{\mathrm{r}}$ (il. 21) i $70^{\mathrm{v}}$ nogi i dzioby ptaków namalowano już na malachitowych łodyżkach (przy czym układ nóg czapli na dolnym marginesie f. $70^{\vee}$ różni się od układu zamierzonego na szkicu); na f. $24^{\mathrm{r}}$, mimo ukończenia bordiury, nogi czapli pozostały w fazie projektu (il. 22). Od tego schematu postępowania zdarzały się sporadyczne odstępstwa. Na f. 126r (il. 17) czapla jest wykończona w całości, włącznie z czerwonym konturem nóg; na stronach $25^{\mathrm{v}}-26^{\mathrm{r}}$ zdecydowano się wprowadzić niezaplanowane wcześniej postaci zwierzęce, które w pospieszny sposób nałożono na precyzyjnie opracowane już bordiury, burząc tym samym ich finezyjną harmonię.

${ }^{61}$ O kolejności świadczy folio $71^{\text {r }}$ - żółte kółeczka na powierzchni strączka są przesłonięte częściowo jego białym wykończeniem, położonym wierzchem. 
Powyższa analiza wskazuje, że przy zdobieniach kodeksu 83 pracował większy zespół dekoratorów o precyzyjnie rozdzielonych zadaniach, choć etapy ich realizacji mogły być zależne od rozdysponowania arkuszy pomiędzy różnych dekoratorów i tempa ich opracowywania. Choć praktyka zdobienia wielkich, nierozciętych arkuszy pergaminu była w tym okresie znana (zwłaszcza w warsztatach produkujących seryjnie), wydaje się, że w przypadku toruńskiego kodeksu dekorowano bifoliae, uporządkowane w składki ${ }^{62}$. Przy dokładnej analizie dekoracji składek można zaobserwować pewna prawidłowość - często dane bifolio jest pozostawione dokładnie w tej samej fazie szkicu, niekiedy jedna jego strona (dająca potem recto i verso dwóch kart) była kończona równocześnie w najdrobniejszych szczegółach, podczas gdy druga w ogóle nie otrzymała dekoracji. Przykładowo, w quaternionie czwartym $\left(19^{\mathrm{r}}-26^{\mathrm{v}}\right)$ pierwsze oraz trzecie bifolio zostały po obu stronach opracowane tak samo - lewą stronę pozostawiono pusta, prawa $\left(19^{\mathrm{r}}\right.$ i $26^{\mathrm{r}}$ oraz $21^{\mathrm{r}}$ i $\left.24^{\mathrm{r}}\right)$ ma dekorację wykończoną w szczegółach, z zastosowaniem wici z zielonej łodyżki. Drugie bifolio składki IV po jednej stronie $\left(20^{\mathrm{r}}\right.$ i $\left.25^{\mathrm{v}}\right)$ jest wykończone w całości tak samo (uderza przy tym zestawienie analogicznych motywów drolerie - pies na marginesie zewnętrznym i paw w bas-de-page), podczas gdy druga strona tego arkusza $\left(20^{\mathrm{v}}\right.$ i $\left.25^{\mathrm{r}}\right)$ jest całkowicie pozbawiona dekoracji. Środkowe bifolio składki po rozłożeniu jest ozdobione po jednej stronie analogicznie $\left(22^{\mathrm{v}}-23^{\mathrm{r}}\right.$, obie bordiury wykończone tak samo, z systemem drobnej dekoracji piórkowej), a po drugiej stronie arkusza mamy zestawienie stronicy bez dekoracji $\left(22^{r}\right)$ ze stronica zaledwie naszkicowaną $\left(23^{v}\right)$.

W całym kodeksie uderza także uchwytna jednolitość stosowanych kompozycji oraz poziomu wykończenia poszczególnych składek. I tak, w składkach VI $\left(35^{\mathrm{r}}-42^{\mathrm{v}}\right)$ i VII $\left(43^{\mathrm{r}}-50^{\mathrm{v}}\right)$ dominują karty z naniesionym, nieukończonym szkicem listowia, podczas gdy karty wykończone cechuja się tym samym typem ornamentu w tle (malachitowe łodyżki w szóstej i ornament piórkowy w siódmej składce). W składce XII (84 $\left.-91^{\mathrm{v}}\right)$ przeważaja karty ze wstępnie wykończonymi postaciami drolerie, a w składce XVI $\left(116^{\mathrm{r}}-123^{\mathrm{v}}\right)$ - kompozycje $z$ winną latorośla. W XIII $\left(92^{\mathrm{r}}-99^{\mathrm{v}}\right)$ dwukrotnie pojawiają się nietypowe kompozycje z aniołami wśród akantu

${ }^{62}$ W ten sam sposób dekorowano Godzinki Katarzyny z Kleve, zob. R. G. Calkins, Distribution of Labor, s. 6. 
$\left(92^{v}, 98^{v}\right)$. Może to wskazywać, że po naniesieniu zasadniczego schematu akantowych ornamentów oraz ram i gwaszowych inicjałów arkusze pogrupowano w docelowe składki i rozdysponowano dekoratorom do wykończenia, co nie było praktyką odosobnioną ${ }^{63}$.

Przeanalizowana metoda twórcza pozwala w nowym świetle spojrzeć na ewentualne ,indywidualności”, czynne przy realizacji toruńskiego kodeksu 83. Jedyny wyróżniający się iluminator ozdobił kartę początkową Godzinek o NMP, $12^{\mathrm{r}}$ - jest to jedyna odmienna stronica w trzeciej składce, pozostała część arkusza dekorował już ktoś inny. Ponieważ zadanie stworzenia dekoracji figuralnej kodeksu powierzano zwykle najbieglejszemu członkowi zespołu, czuwającemu nad cała koncepcją, w autorze tego inicjału można upatrywać głównego pictora w tym warsztacie. Zwraca uwagę, że wykonana przez niego bordiura ${ }^{64}$ jest najbardziej indywidualna ze wszystkich marginalnych dekoracji kodeksu. Mogła ona stanowić dla pozostałych dekoratorów tzw. kompozycję wzorcową, naśladowaną przede wszystkim w tych kartach, które zostały wykończone malachitową łodyżką z pączkami. Nie można wykluczyć, że rola pictora ograniczała się tylko do wykonania głównych motywów malarskich ${ }^{65}$ (w tym także domniemanej miniatury ze Zwiastowaniem na niezachowanym folio, poprzedzającym kartę $\left.12^{\mathrm{r}}\right)$. Trzy pozostałe duże inicjały w tekście, choć wyróżniają się skalą i w typie sa zbliżone do incipitu, mają nieco inne kształty pól i być może wyszły spod innej ręki. Zwraca natomiast uwagę, że w przypadku dwóch spośród kart incipitowych $\left(53^{\mathrm{r}}-\right.$ il. $\left.7,6^{\mathrm{r}}\right)$ ich twórca wyraźnie naśladował bordiurę $12^{\mathrm{r}}$, wprowadzając liście o barwie cynobrowej oraz zielono-czerwone pączki ostu, odmienne od tych na pozostałych foliałach.

Reszta bordiur, jak się wydaje, jest dziełem większej liczby dekoratorów. Fakt, że partie figuralne nie były planowane wraz z komponowaniem listowia czy obramień, lecz nanoszone wcześniej, przemawia na korzyść

63 Zob. J. J. G. Alexander, op. cit., s. 49; oraz Zdobienie, pod red. P. Stirnemann, [w:] Jak czytać rękopis średniowieczny, pod red. P. Gréhina, Warszawa 2008, s. 114.

${ }^{64}$ Calkins wskazuje, że w warsztatach północnoniderlandzkich miniaturzysta bywał odpowiedzialny za bordiury, towarzyszace miniaturom, stąd wniosek, że przedstawienie inicjałowe NMP i floraturę wykonał ten sam malarz. R. G. Calkins, Stages of execution: procedure of illumination as revealed in an unfinished Book. of Hours, „Gesta”, 1978, vol. 17/1, s. 63 oraz s. 67, przyp. 9.

65 J. J. G. Alexander, op. cit., s. 49. 
teorii, iż wykonywał je wyspecjalizowany iluminator (być może sam główny pictor, na co wskazywałaby stylistyka postaci niedźwiednika ${ }^{66}$ ). Posługiwał się on jednym, dość standardowym zasobem modeli. Poszczególne motywy powtarzają się i są silnie stypizowane - jak półfigury aniołów, małpki na $2^{\mathrm{r}}$ i $4^{\mathrm{r}}$, pawie czy dwa wyobrażenia smoka na folio $89^{\mathrm{r}}$. Być może inny iluminator (iluminatorzy?) - specjalista od ornamentu - wykonywał wici roślinne, a opisana metoda postępowania, zwłaszcza w partii akantu (liść - walor - kontur - perełkowanie grzbietu), odpowiadała wspomnianej już praktyce warsztatowej, poświadczonej przez wzornik Getyngi ${ }^{67}$, którego instruktażową autentyczność kodeks 83 zdaje się pośrednio potwierdzać ${ }^{68}$. Oczywiście, nie można też wykluczyć, że kompozycje roślinne z winną latoroślą malował kto inny. Trudno też orzec, czy drobniejsze elementy wykończenia (jak ornament piórkowy) wykonali sami dekoratorzy, czy np. pomocnicy, zajmujący się także być może podmalowywaniem inicjałów ${ }^{69}$. Jak wskazywała Barbara Miodońska, podział pracy w obrębie późnośredniowiecznego warsztatu wytwarzającego księgi mógł zależeć od różnych czynników, a w przypadku dzieł szczególnie obfitych w dekoracje sposoby podziału pracy mogły się krzyżować ${ }^{70}$. Dla kodeksu 83 stosowania takiej właśnie praktyki dowodzi analiza systemu ornamentów w poszczególnych składkach i wyjątki od omówionych reguł, czytelne niemal na każdym etapie wykonywania dekoracji. Odstępując od proponowanego niegdyś przez Alicję Karłowską-Kamzową podziału atrybucji pomiędzy dwu mistrzów, nie rozstrzygniemy jednak ostatecznie o liczbie „rąk”, zatrudnionych przy tej pracy. Pytanie, dlaczego nigdy jej nie ukończono, po-

${ }^{6}$ Zdaniem Alexandra wolne miejsca, pozostawione na bordiurze manuskryptu Mistrza Zwiastowania z. Aix i Enguerranda Quartona, miały być wykończone przez autora miniatur. J. J. G. Alexander, op. cit., s. 49.

67 H. Lehmann-Haupt, op. cit.

68 Co jest o tyle istotne, że Harry Bober powątpiewał w domniemaną wzornikową funkcję rękopisu z Getyngi, upatrując w nim raczej rodzaju podręcznika dla wydawców wczesnych ksiag drukowanych, dysponujących słabo wykwalifikowana grupa dekoratorów. Zob. H. Bober, Review [H. Lehmann-Haupt, The Göttingen], „Speculum", 1974, vol. 49, s. 354-358. Zob. także R. G. Calkins, Stages of execution, s. 61 i s. 66 (przyp. 3).

69 B. Miodońska, op. cit., s. 344.

70 Ibidem. 
zostaje również bez odpowiedzi, choć jednolitość oddziaływania całości, luksusowe materiały i hierarchizacja dekoracji świadczą o tym, że manuskrypt z powodzeniem mógł być przez warsztat sprzedany i funkcjonować w prywatnym ususie dewocyjnym.

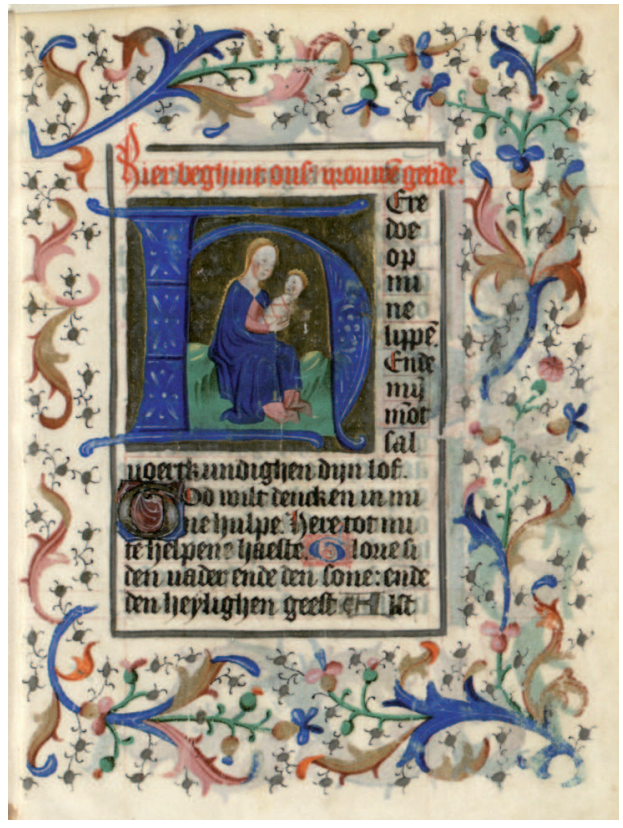

Il. 1. Modlitewnik $83 / \mathrm{I}$, f. $12^{\mathrm{r}}$ (karta ukończona). Karta incipitowa z inicjałem figuralnym (fot. Biblioteka Uniwersytecka w Toruniu - P. Kurek) 

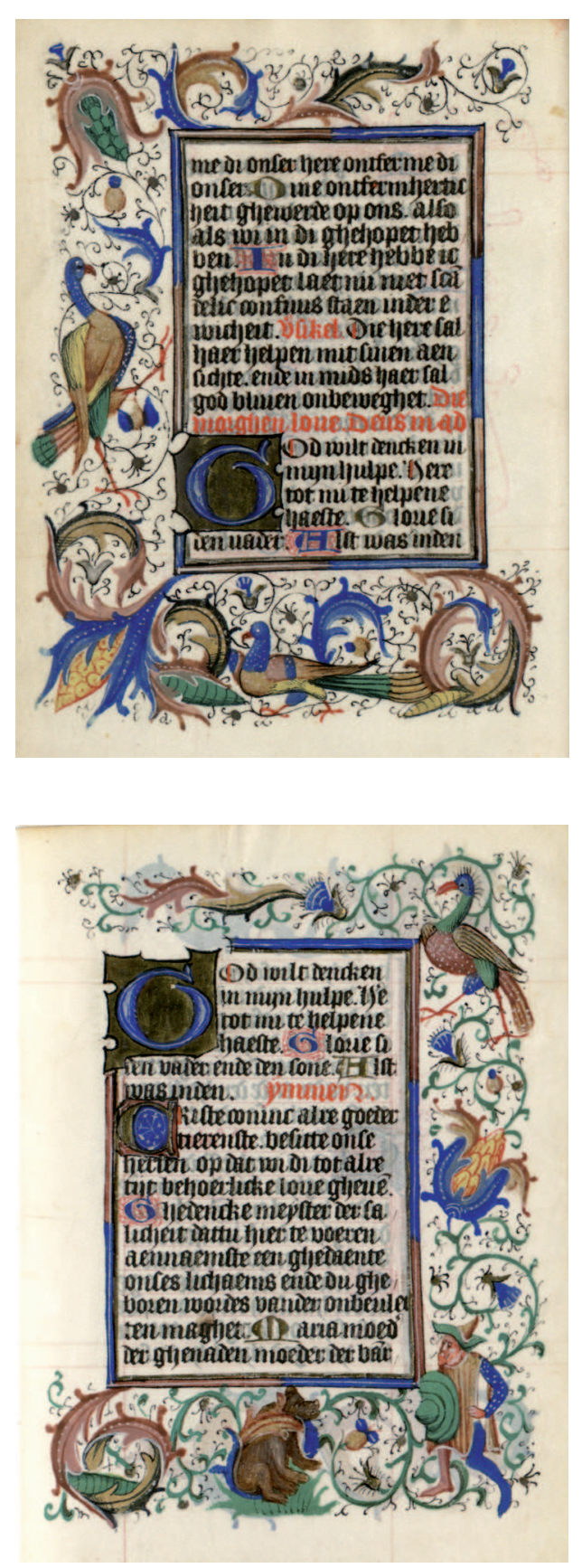

Il. 2. Modlitewnik 83/I, f. $22^{\mathrm{v}}$ (karta ukończona). Duży inicjał na złotym polu; wykończona bordiura z liści akantu, z drobnym piórkowym ornamentem $\mathrm{w}$ tle, $\mathrm{z}$ motywem szyszek w narożach i $z$ wplecionymi postaciami rajskich ptaków (fot. Biblioteka Uniwersytecka w Toruniu - P. Kurek)

Il. 3. Modlitewnik $83 /$ I, f. $40^{\mathrm{r}}$ (karta ukończona). Duży inicjał na złotym polu, inicjał średni w ramce oraz drobne inicjały kaligraficzne; wykończona w całości bordiura z liści akantu, tło wypełnione zieloną wicią roślinna, uzupełnioną ornamentem piórkowym, z motywem szyszki, strączka oraz motywami figuralnymi: rajski ptak, niedźwiedź i niedźwiednik (fot. Biblioteka Uniwersytecka w Toruniu - P. Kurek) 

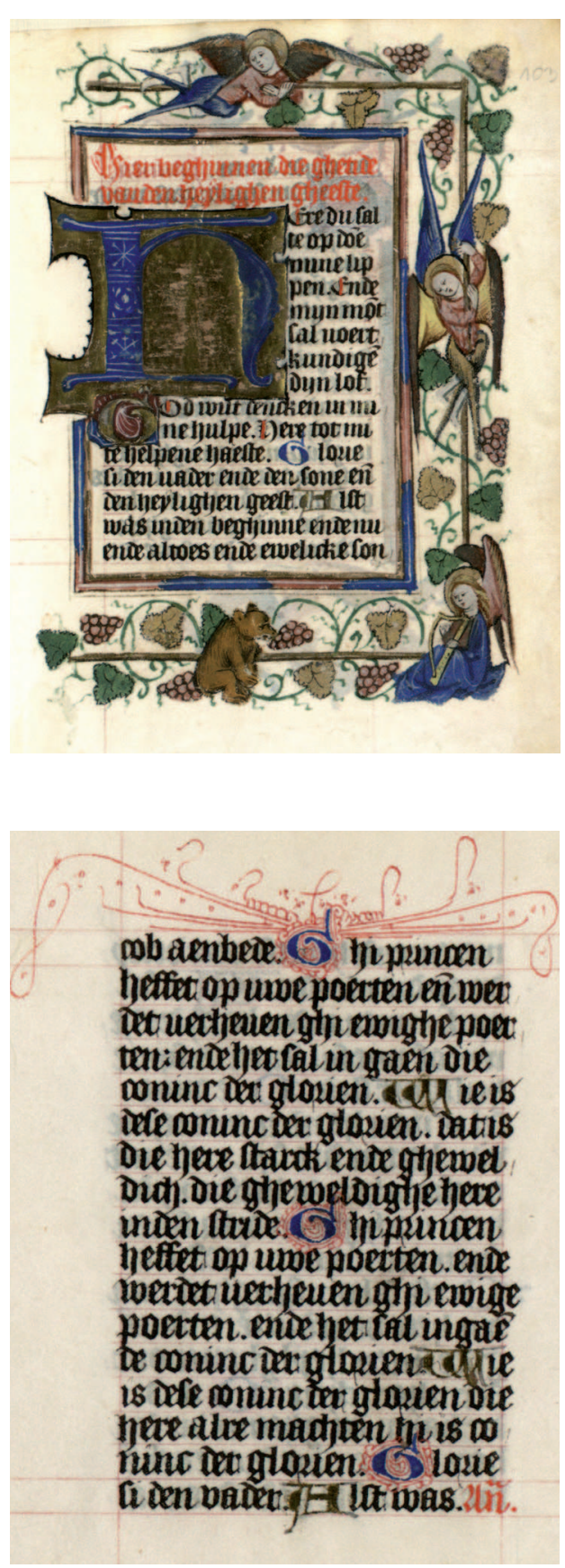

Il. 4. Modlitewnik 83/I, f. $103^{\text {r }}$ (karta ukończona). Bordiura $\mathrm{z}$ wici winnej latorośli wokół złotej listwy, z wplecionymi półpostaciami serafinów, $\mathrm{w}$ bas-de-page muzykujący anioł oraz niedźwiedź (fot. Biblioteka Uniwersytecka w Toruniu - P. Kurek)
Il. 5. Modlitewnik $83 / \mathrm{I}$, f. $17^{\mathrm{v}}$ (karta bez bordiury roślinnej). Widoczna dekoracja kaligraficznego inicjału z wypustkami (fot. Biblioteka Uniwersytecka w Toruniu - P. Kurek) 


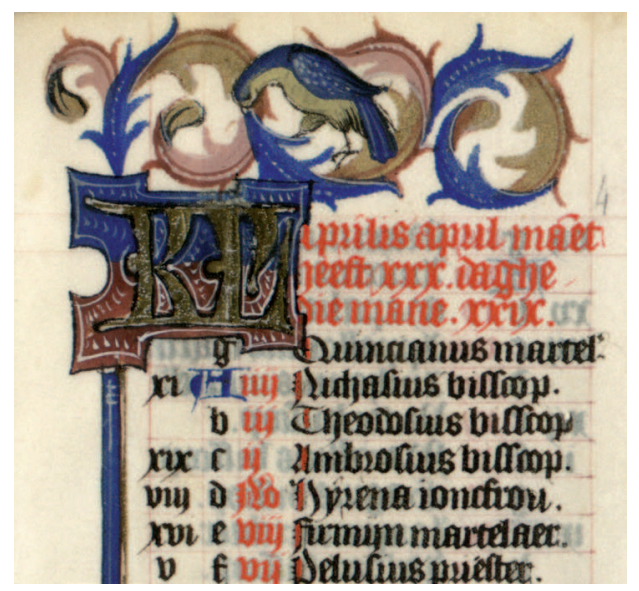

Il. 6. Modlitewnik 83/I, f. $4^{\mathrm{r}}$ (karta nieukończona?) - fragment. Inicjał średni w ramce, litera złocona, tło malowane gwaszem; liście akantu wykończone w pełni; dziób ptaka nieukończony (fot. M. Jakubek-Raczkowska)

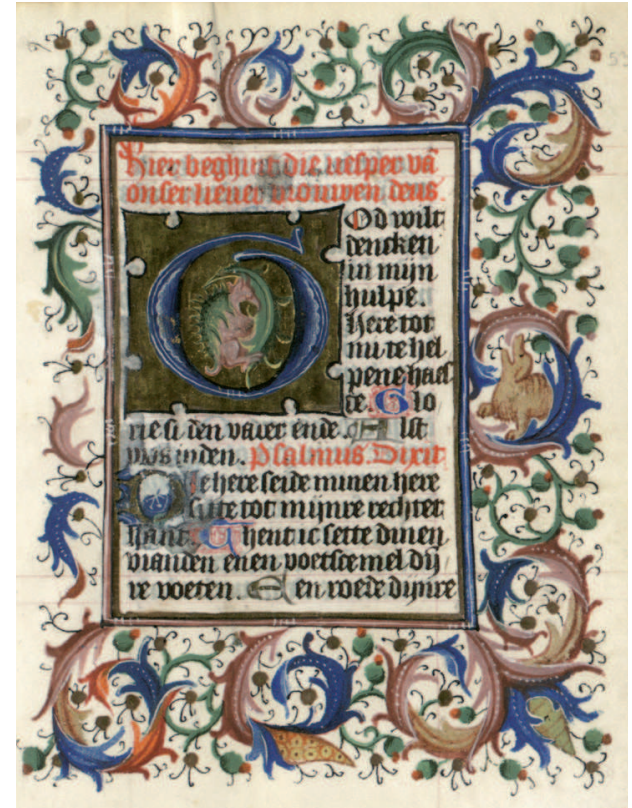

Il. 7. Modlitewnik $83 /$ I, f. $53^{\text {r }}$ (karta ukończona). Bordiura $\mathrm{z}$ tłem wypełnionym malachitowymi gałązkami, zakończonymi pączkami ostu; inicjał duży na złotym tle, z motywem hybrydy (fot. Biblioteka Uniwersytecka w Toruniu - P. Kurek) 

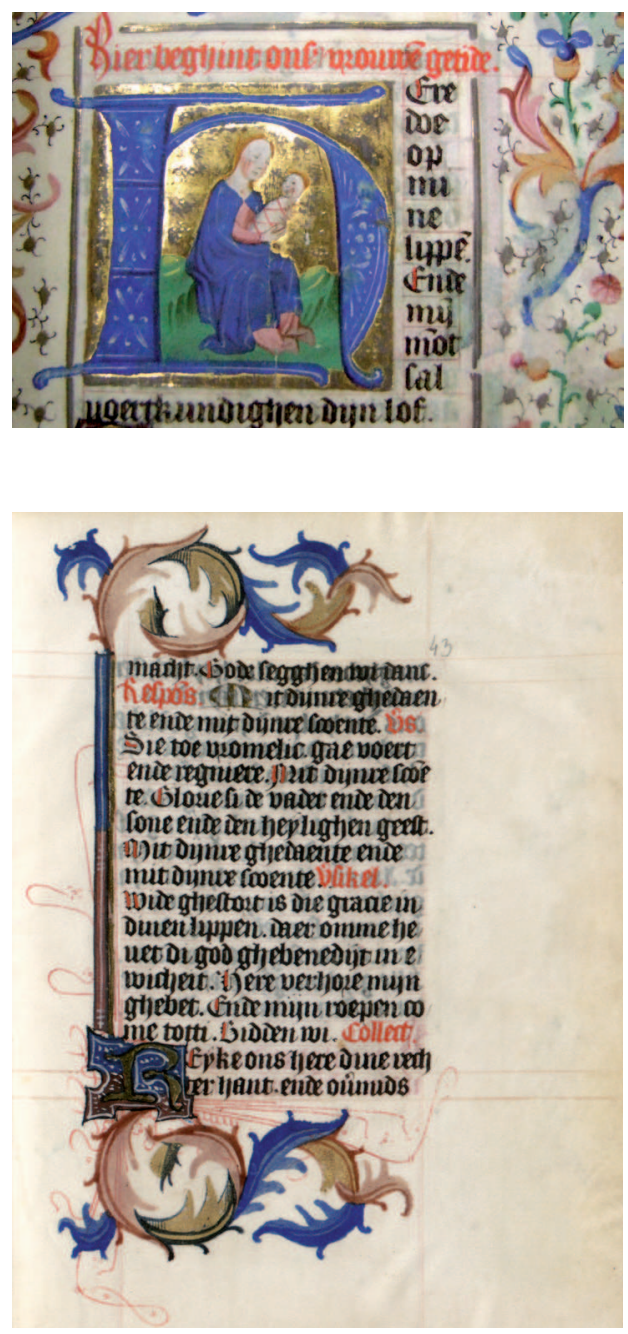

Il. 8. Modlitewnik 83/I, f. $12^{\mathrm{r}}$ (karta ukończona) - fragment. Inicjał figuralny z Matką Bożą z Dzieciątkiem (fot. M. Jakubek-Raczkowska)

Il. 9. Modlitewnik 83/I, f. $43^{\text {r }}$ (karta nieukończona). Akantowe wypustki, bez ostatecznego wykończenia; widoczne kaligraficzne wypustki inicjału, przysłonięte w większości gwaszowym wykończeniem inicjału i akantów (fot. Biblioteka Uniwersytecka w Toruniu P. Kurek) 


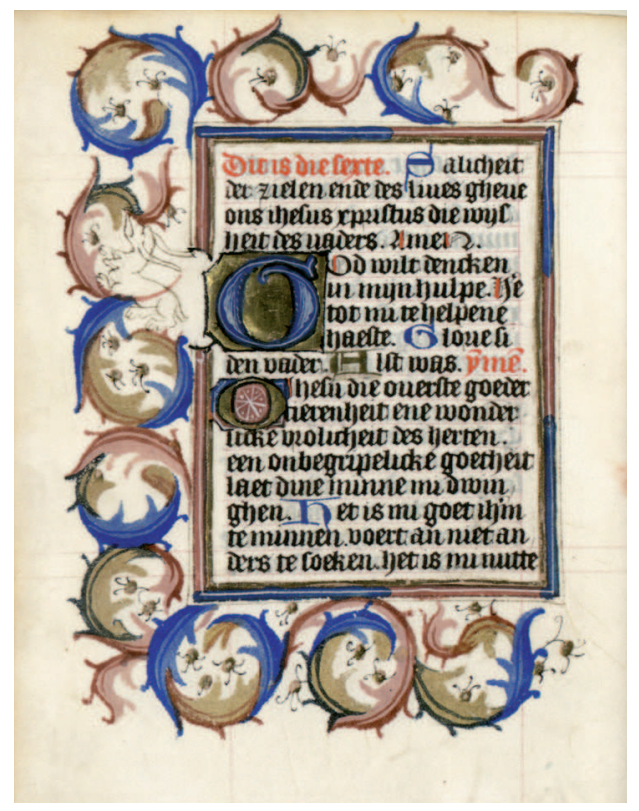

Il. 10. Modlitewnik 83/I, f. $90^{\mathrm{v}}$ (karta nieukończona). Kompozycja akantowa bez wykończenia, z rozpoczętym, piórkowym wypełnieniem tła pomiędzy liśćmi akantu oraz pozostawionym w fazie szkicu motywem smoka (fot. Biblioteka Uniwersytecka w Toruniu P. Kurek)

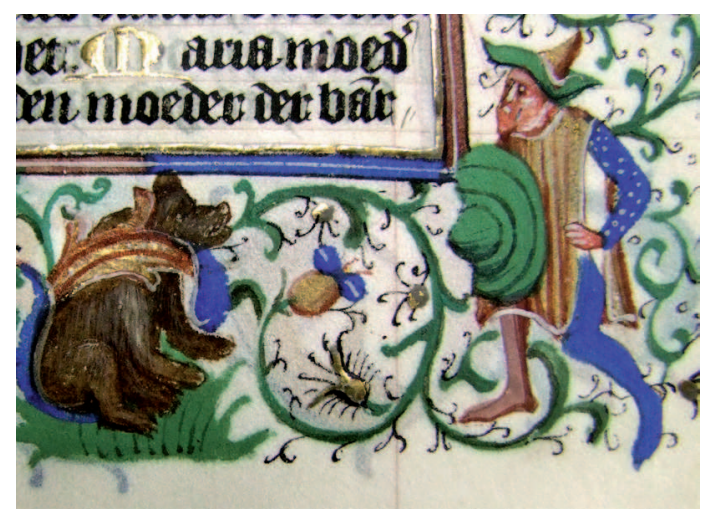

Il. 11. Modlitewnik 83/I, f. $40^{\mathrm{r}}$ (karta ukończona) - fragment. Postać niedźwiadka wykończona czarną kreską, detale postaci niedźwiednika uzyskane biela (fot. M. Jakubek-Raczkowska) 

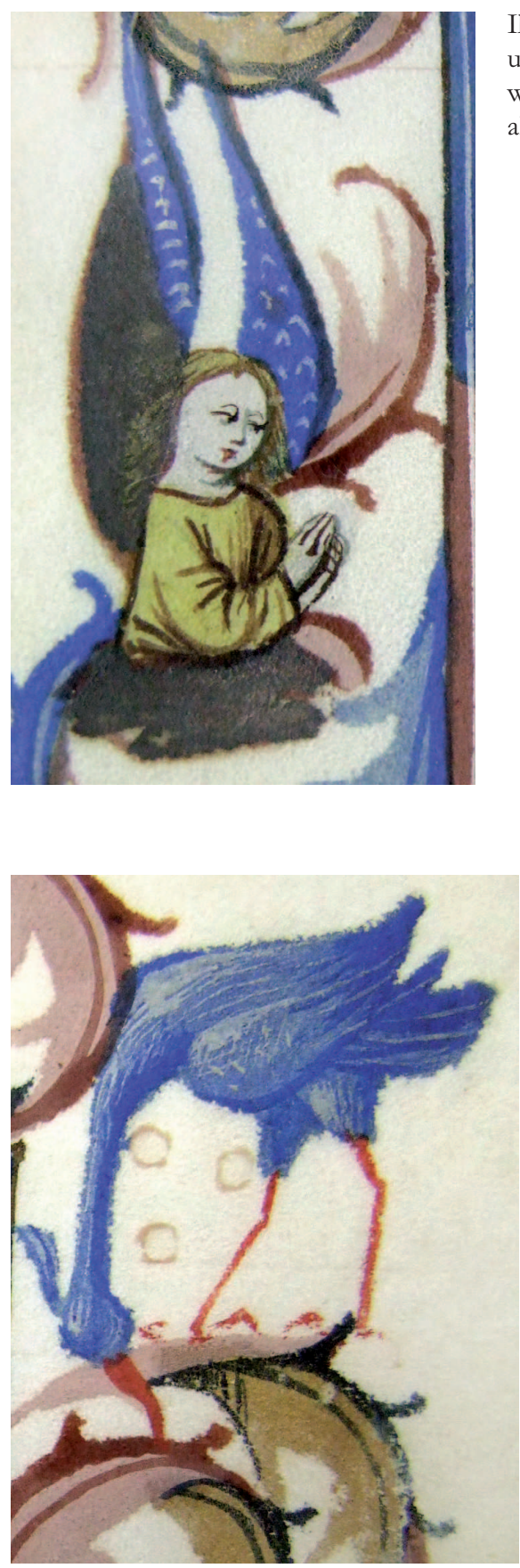

Il. 12. Modlitewnik 83/I, f. 92 (karta nieukończona) - fragment. Półfigura anioła, wyjątkowo wprowadzona w obręb bordiury akantowej (fot. M. Jakubek-Raczkowska)
Il. 13. Modlitewnik 83/I, f. $126^{\mathrm{v}}$ (karta nieukończona) - fragment. Nieukończona postać czapli z wmalowanymi białymi piórkami, widoczne projekty złotych ziarenek w tle (fot. M. Jakubek-Raczkowska) 


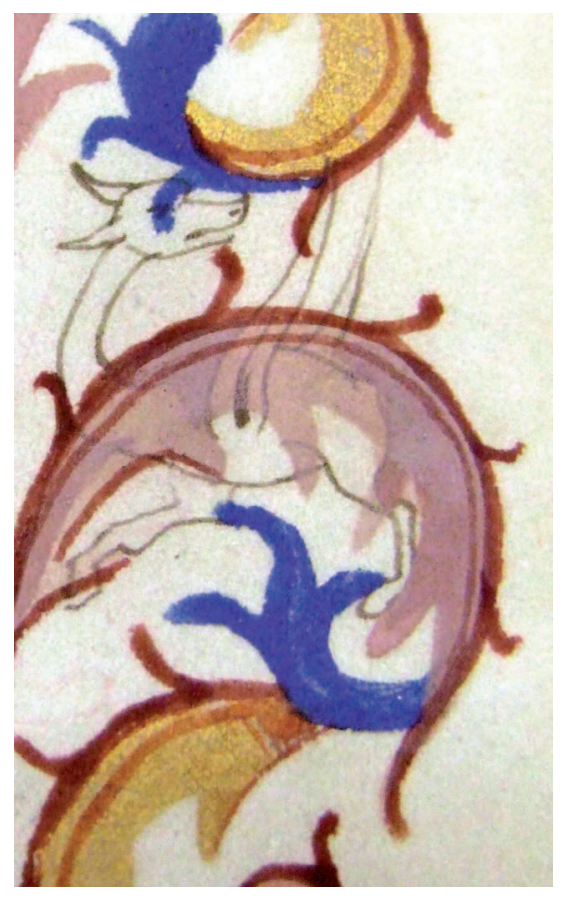

Il. 14. Modlitewnik 83/I, f. 59 (karta nieukończona) - fragment. Szkic postaci smoka, naniesiony ugrowym konturem, przykryty liśćmi akantu (fot. M. Jakubek-Raczkowska)

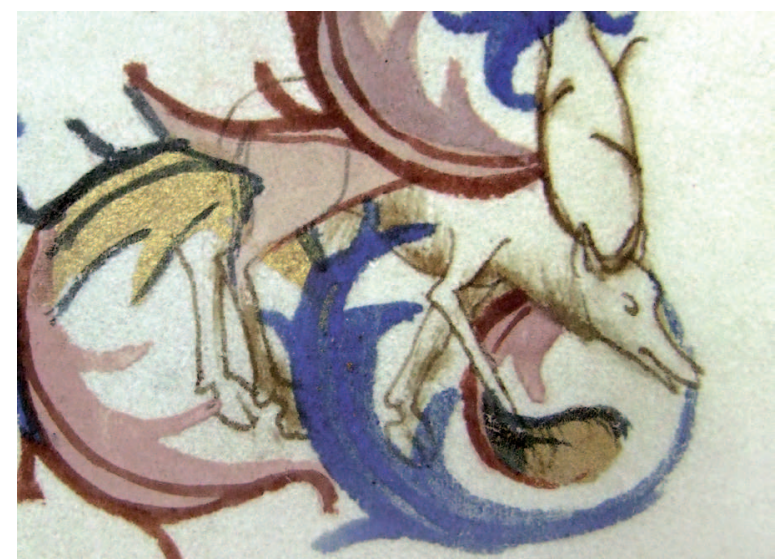

Il. 15. Modlitewnik 83/I, f. $59^{\mathrm{r}}$ (karta nieukończona) - fragment. Szkic postaci jelenia $z$ próba cieniowania, dukt liści akantu celowo przerywany (fot. M. Jakubek-Raczkowska) 


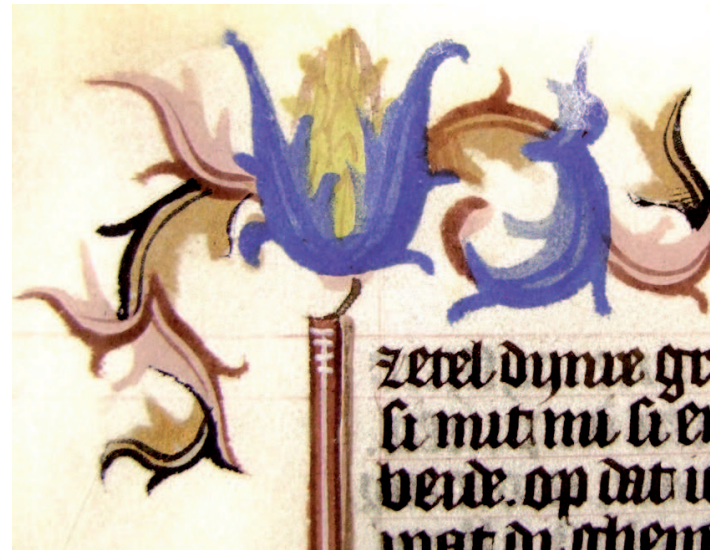

Il. 16. Modlitewnik 83/I, f. $76^{v}$ (karta nieukończona) fragment. Nieukończony ornament akantowy $z$ motywem szyszki (bez wykończenia) (fot. M. Jakubek-Raczkowska)

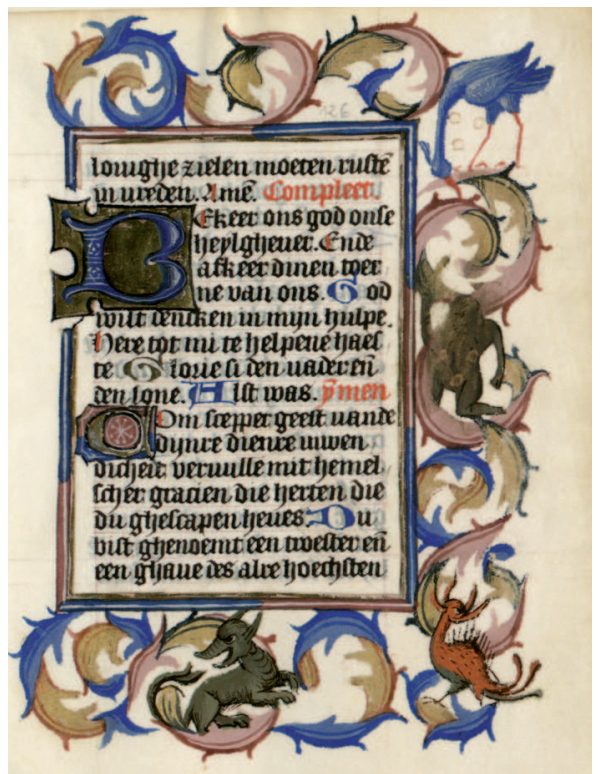

Il. 17. Modlitewnik $83 /$ I, f. $126^{\mathrm{v}}$ (karta nieukończona) - fragment. Naniesiona kolorystyczna kompozycja akantu bez wykończenia, brak wypełnienia tła, wykończone motywy drolerie (fot. Biblioteka Uniwersytecka w Toruniu - P. Kurek) 


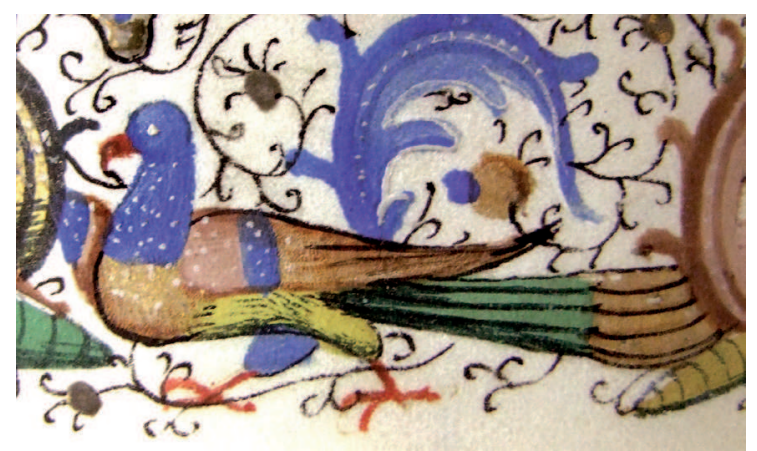

Il. 18. Modlitewnik 83/I, f. $22^{v}$ (karta ukończona) fragment. Postać pawia malowana wielobarwnie gwaszem i wykończona czarnym konturem; tło bordiury pomiędzy akantami wypełnione piórkową „pajęczynką” (fot. M. Jakubek-Raczkowska)

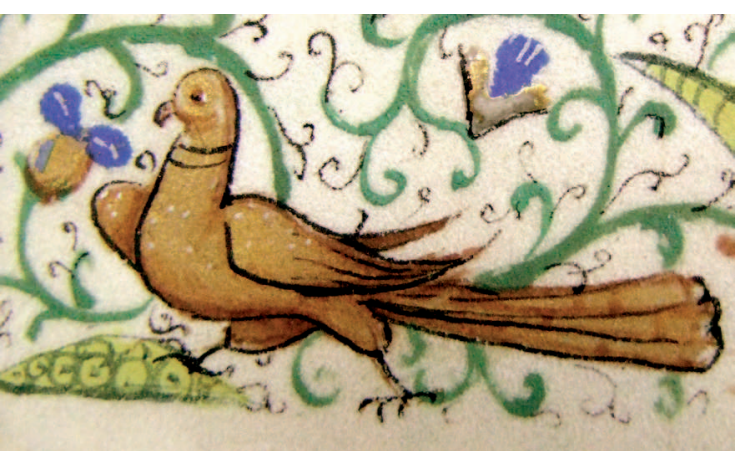

Il. 19. Modlitewnik 83/I, f. 24 (karta ukończona) - fragment. Postać pawia malowana sproszkowanym złotem i wykończona czarnym konturem (fot. M. Jakubek-Raczkowska)

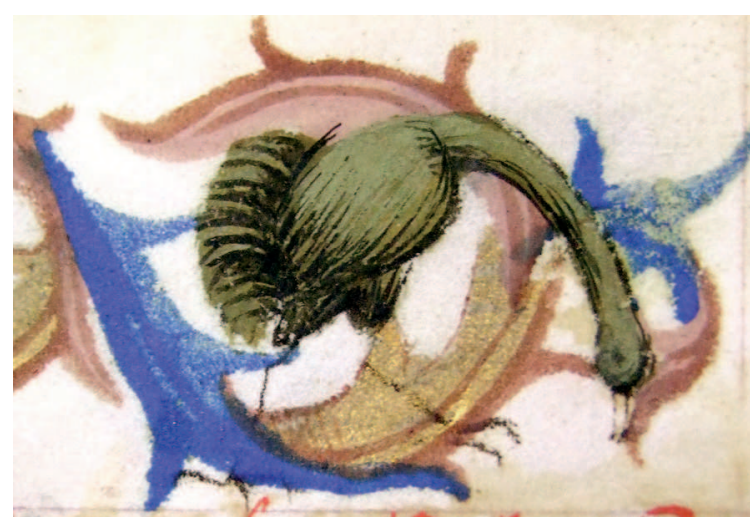

Il. 20. Modlitewnik 83/I, f. $2^{\text {r }}$ (karta nieukończona)

- fragment. Postać ptaka, opracowana za pomoca pospiesznego kreskowania, nogi i dziób pozostawione w fazie szkicu (fot. M. Jakubek-Raczkowska) 

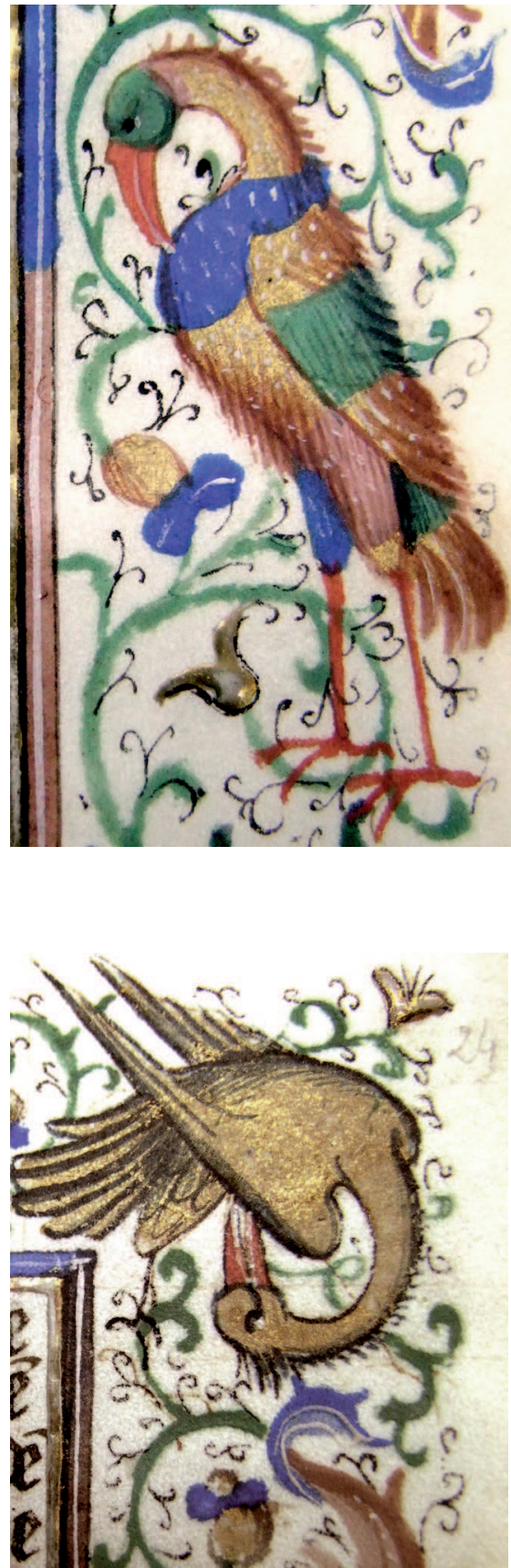

Il. 21. Modlitewnik 83/I, f. $61^{\mathrm{r}}$ (karta ukończona) - fragment. Postać ptaka, nogi i dziób malowane po ukończeniu piórkowego ornamentu w tle (fot. M. Jakubek-Raczkowska)
Il. 22. Modlitewnik 83/I, f. 24r (karta ukończona, bez drobnych detali) - fragment. Postać ptaka malowana sproszkowanym złotem i wykończona czarnym konturem, lewa noga ptaka w fazie szkicu, prawa ukończona pospiesznie piórkiem, bez uwzględnienia wcześniejszego projektu (fot. M. Jakubek-Raczkowska) 


\section{Summary}

\section{The Netherlandish Prayer Book 83 from Toruń collection - contribution to the studies on illuminators' workshop of the late Middle Ages}

The subject of the analysis is a codex Geert Groote Cannonical Hours (cod, 83/I) from the Special Collection of the University Library in Torun, up till 1945 being a part of collection of the Staats- und Universitätsbibliothek in Königsberg. It is one of more interesting, luxurious devotional books in Torun collection, richly decorated with initials and floral bordures with drolerie motifs on the margins. It has been introduced to the literature by Alicja Karłowska-Kamzowa, but so far it have not had a full monograph and the information on its provenance and dating have to be revised.

The codex, written in low-Netherlandish language with Latin insertions and preceded with a calendar of the Utrecht Diocese, most probably made a book of private usus (probably of a lay person). Basing on the analysis of the style of figural parts, the applied composition schemes and numerous ornamental motifs one can assume that it was made in the North-Netherland environment (circle of "Masters of Otto van Moerdrecht") and shift its dating (once established by Alicja Karłowska-Kamzowa to the turn of $15^{\text {th }}$ century) towards the second quarter of $15^{\text {th }}$ century.

An important research issue in case of the codex is the division and systematics of work within the illuminators' workshop, perceptible thanks to leaving numerous parts without the final finish. A thorough analysis of the technique of making the ornaments allows to trace the subsequent stages of work and its "conveyor-belt" organisation as well as to point out the reasons for "hierarchisation" of tasks. The features of ornamentation systems in the gatherings and the exceptions from the perceptible rules allow for looking at the "individualities" active at the execution of that codex in a new light. The creative method studied in the present paper allows to resign from attributing the work to just two masters, however the number of decorators is hard to be decided on. Also unanswered remains the question of the reasons why the work has not been completed. 